\title{
Linking the sediment geochemistry of an intertidal region to metal bioavailability in the deposit feeder Macoma balthica
}

\author{
Christine A. Thomas, Leah I. Bendell-Young* \\ Dept of Biological Sciences, Simon Fraser University, 8888 University Ave, Burnaby, British Columbia V5A 1S6, Canada
}

\begin{abstract}
Surficial sediment and biota samples were collected from 26 locations in the intertidal region of the Fraser River estuary (British Columbia, Canada). Sediment samples were collected in May and July of 1995. Benthic samples of Macoma balthica, a deposit feeding bivalve, were collected from each site in July. Sediments were characterized by a simultaneous extraction procedure that characterized the sediment matrix into oxides of manganese and iron (easily reducible Mn, ER Mn, and reducible $\mathrm{Fe}, \mathrm{RED} \mathrm{Fe}$ ) and organic matter and separated the trace metals, cadmium, copper, lead, nickel and zinc among these 3 'biologically relevant' sediment components, i.e. metals associated with ER Mn, RED Fe and organic matter. Total mercury was also determined in each sediment sample. Bivalve samples were separated into shell and tissue and analysed for the same metals. An $\mathrm{R}^{2} \mathrm{MAX}$ procedure was applied to determine if the concentration of trace metals in the shell and tissue of $M$. balthica was related to sediment geochemistry using sediment geochemistry and bivalve metal concentrations as the independent variable and dependent variable respectively. The partitioning of trace metals was dependent on the location-specific geochemistry (i.e. amounts of ER Mn, RED Fe and organic matter recovered at each location). This in turn led to differences in metal uptake by $M$. balthica that were related to sediment geochemistry. The relationships with tissues were highly significant $(p \leq 0.001)$, except for mercury $(p \leq 0.05)$. Sediment geochemistry accounted for $31 \%$ of the variability for cadmium, $39 \%$ for zinc, $51 \%$ for copper and $54 \%$ for lead Relationships were not as strong for shells; sediment geochemistry explained $12 \%$ of the variation for mercury, $15 \%$ for zinc, $21 \%$ for nickel and $43 \%$ for copper. Overall, metal levels in the tissue and shell of $M$. balthica were best related to the concentration of metal associated with the ER Mn component of sediment. The sediment geochemical matrix as defined by ER Mn, RED Fe and organic matter and the partitioning of trace metals among the 3 fractions was highly site-specific. This in turn led to site-specific patterns in metal bioavailability to $M$. balthica. The spatial heterogeneity that occurs within an estuary, on the scale of metres, must be considered when assessing the impact of metals on such regions.
\end{abstract}

KEY WORDS: Sediment geochemistry Metal bioavailability Macoma balthica

\section{INTRODUCTION}

Estuarine sediments are a major reservoir of trace metals, both of anthropogenic and natural origins (Bryan et al. 1980, Langston 1982). Once in the sediment, these metals can be accumulated by benthicdwelling organisms which live and feed on the sediment (Engel \& Fowler 1979, Tessier et al. 1994). Considering that benthic organisms are primary prey items for several higher trophic levels (shorebirds,

-Addressee for correspondence. E-mail: bendell@sfu.ca waterfowl, fish, etc.), transfer of metals to the next trophic level can occur over time (Braune 1987, Young et al. 1987, Ferns \& Anderson 1994). In addition, elevated tissue concentrations of metals can lead to adverse effects in biota (Roesijadi 1992, Luoma et al. 1995a).

Aquatic sediments are composed of several different geochemical phases that can act as potential sinks for metals entering an estuarine system. These phases include clay, silt, sand, organic material, oxides of iron, manganese, aluminium and silica, carbonates and sulphide complexes (Shea 1988). Of these components, 
oxides of iron and manganese and organic matter are considered the most important geochemical components controlling metal binding in the oxidized portion of estuarine sediment (Jenne 1968, Luoma \& Bryan 1981, Davies-Colley et al. 1984). Metal availability is affected by the metal's association with one or more of these sediment components; hence, total metal concentrations provide little information about potential interactions between the abiotic and biotic environments. Therefore, knowledge of the partitioning of a particular metal among these 3 sediment components is necessary to provide for better estimates of metal bioavailability.

Macoma balthica, primarily a deposit-feeding bivalve, is found throughout the Fraser River estuary and has been used frequently to monitor the levels of bioavailable metals in the sediment (Bryan et al. 1980, Langston 1982). Specifically, $M$. balthica has been used as an indicator of metal contamination for mercury, lead, silver and arsenic in several estuaries (Bryan \& Hummerstone 1977, Langston 1985, Bordin et al. 1992). Because the bivalves are in intimate contact with the sediments and feed mainly on the surficial sediments (they will occasionally filter-feed on suspended sediments) (Harvey \& Luoma 1985), their tissue concentrations tend to be indicative of bioavailable metals in the sediment. Hence, the correlations between levels of metals found in the different sediment fractions and tissue levels in $M$. balthica should give an indication of the primary source of metal contamination, as well as an indication of the geochemical components that inhibit or promote the uptake of metals by sediment-ingesting organisms

A question often raised in studies involving bivalves as indicators of metal contamination is whether or not the shell should be analysed in addition to the tissue. In most cases, only tissues are used, as they respond faster to changes in the environment and tend to have higher metal concentrations than shells (Koide et al. 1982, Walsh et al. 1995). However, there is little information relating metal concentrations in the soft tissue to those in the shell of bivalves. Metal ions can become incorporated into the crystalline structure of the shell by replacing calcium in the carbonate complex or by association with the organic component of the shell (Babukutty \& Chacko 1992). Previous studies have shown that analyses of shell material and tissues complement one another, given that tissues have an inherently higher variability in their trace metal contents due to factors such as season, age, size and weight (Cain \& Luoma 1986, Soto et al. 1995).

The objectives of this study were therefore, first, to characterize and contrast the geochemistry of the trace metals cadmium, copper, nickel, lead, zinc and mercury within the intertidal region of the Fraser River estuary (British Columbia, Canada), and second, to relate differences in trace metal geochemistry to metal bioavailability in Macoma balthica. A third objective was to evaluate the use of either shell or tissues as indicators of metal exposures in benthic organisms

\section{MATERIALS AND METHODS}

Study area. The Fraser River estuary is one of the most extensive and productive biological systems in Canada (Kennett \& McPhee 1988, Fraser River Action Plan 1995). It also lies in Canada's third largest urban region, with the basin area containing one-half of the population of British Columbia (Environment Canada 1992). This leads to conflicting demands on the Fraser River which make proper management and monitoring of this system essential. Through various monitoring programs within the Fraser River intertidal area, levels of metals have been measured sporadically and in isolated areas; however, no studies have addressed the geochemistry of metals across the entire intertidal region as related to metal availability.

The Fraser River is the largest river in British Columbia, extending $1378 \mathrm{~km}$ in length and draining an area of approximately $230000 \mathrm{~km}^{2}$ or $25 \%$ of the land area of British Columbia. Approximately $25 \mathrm{~km}$ upstream from the mouth, the river bifurcates into the North Arm and the South Arm (Fig. 1). The North Arm, which carries ca $16 \%$ of the total river discharge, bifurcates again at Richmond, where ca $30 \%$ of the flow (ca $5 \%$ of the total Fraser River flow) exits via the Middle Arm onto Sturgeon Bank while the remaining $70 \% \quad 19 \%$ of the total flow) exits just north of Sturgeon Bank (Feeney 1995). The South Arm carries the majority of the flow and exits onto Roberts Bank (Kennett \& McPhee 1988).

Study sites. Sites and locations along the lower Fraser River estuary intertidal zone were chosen to reflect a range of conditions such as: influence from the Fraser River, grain size and percent composition of organic matter in the sediment. These differences all have implications with regards to metal partitioning and availability. The sampling design allowed for a broad survey of the existing conditions at one point in time across this extensive area. Three sites within the intertidal region were sampled (Fig. 1). (1) The most northerly site, Sturgeon Bank, is estimated to receive ca $15 \%$ of the industrial and municipal wastes discharged into the Fraser River (Fraser River Estuary Study 1979, Feeney 1995). Before 1988, Sturgeon Bank received primary treated sewage from the Iona Island Sewage Treatment Plant (STP) directly onto its foreshore. The discharge from the Iona Island STP amounts to the largest single municipal sewage dis- 


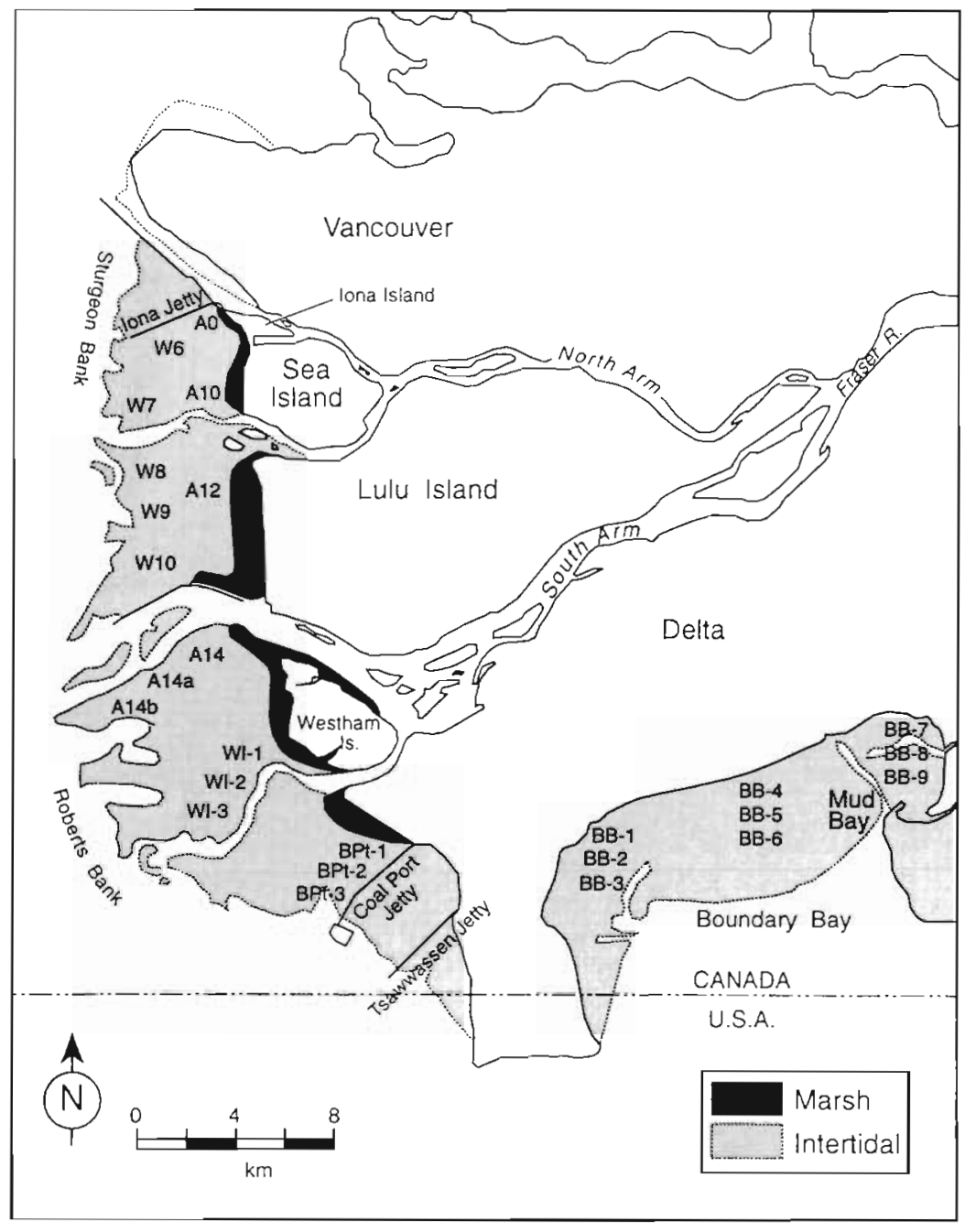

Fig. 1. Sampling locations within the Fraser River intertidal region, British Columbia

The pump stations are located along the west and north shores of the Bay. Both Roberts Bank and Boundary Bay had 9 sampling locations per site, whereas Sturgeon Bank had 8 for a total of 26 sampling locations.

Sediment geochemistry. Sediment samples from all sites were collected during both May and July. At each sampling location, sediment samples were collected in triplicate by skimming the upper oxidized layer of the sediment with a plastic scoop into $50 \mathrm{ml}$ centrifuge tubes. Only the oxic portion of the sediment (top 1 to $5 \mathrm{~mm}$ ) was sampled as this represents the fraction of sediment that provides the greatest source of available metals to organisms (Luoma \& Davis 1983), as well as being the biologically relevant portion of the sediment, i.e. the majority of organisms live and feed in this fraction (Luoma \& Bryan 1981). After collection, sediments were immediately taken to the laboratory and centrifuged at $6500 \mathrm{rpm}$ for 30 min at which time the porewater was pipetted off (Rapin et al. 1986). To minimize microbial alteration, sediments were kept at $4^{\circ} \mathrm{C}$ for a maximum of 48 h until processing.

Sediment samples ( $2 \mathrm{~g}$ wet weight) were subjected to the simultaneous extraction procedure of Bendell-Young et al. (1992) (Fig. 2). The procedure estimates the concentration of metals partitioned onto operationally defined

charge in British Columbia and contains trace metals such as copper, iron, lead, mercury, nickel and zinc (Tevendale \& Eng 1984). In 1988 a new deep-sea outfall was completed which diverted the discharge of sewage into the Strait of Georgia, $90 \mathrm{~m}$ below the surface. The outfall ended the direct discharge of sewage effluent onto Sturgeon Bank, allowing the banks to slowly rehabilitate, with rehabilitation being closely monitored. (2) Roberts Bank. Roberts Bank receives ca $80 \%$ of the total flow of the Fraser River but is estimated to receive $60 \%$ of the municipal and industrial effluent discharged into the Fraser River (Fraser River Estuary Study 1979). (3) Boundary Bay. Water quality at Boundary Bay is influenced via outflows from 3 freshwater rivers, the Serpentine, Nicomekl and Little Campbell. In addition, the areas surrounding Boundary Bay are zoned and utilized for agricultural purposes and drainage from these areas enters Boundary Bay from 5 land pump stations (Swain \& Walton 1994). geochemical components of the sediment: easily reducible (associated with manganese oxide phase); reducible (associated with manganese and iron oxide phase); organic (organically bound); and aqua regia (near total digest) The easily reducible extraction removes metals bound to manganese oxides and all easily extractable components including phosphates, carbonates and reactive iron. The reducible extract removes easily reducible metals (those bound to manganese oxides) and the reducible metals (those bound to iron oxides). The actual reducible metals are determined after analysis by subtracting the easily reducible fraction from the reducible fraction. Digestions such as aqua regia $\left(3: 1 \mathrm{HCl}: \mathrm{HNO}_{3}\right)$ are considered 'near total' digests of the sediment and dissolve most of the heavy metals in the fine grained sediments, including cadmium, copper, lead, mercury, silver and zinc. The amount of metal in the residual phase was estimated as aqua regia minus the other 3 phases. 


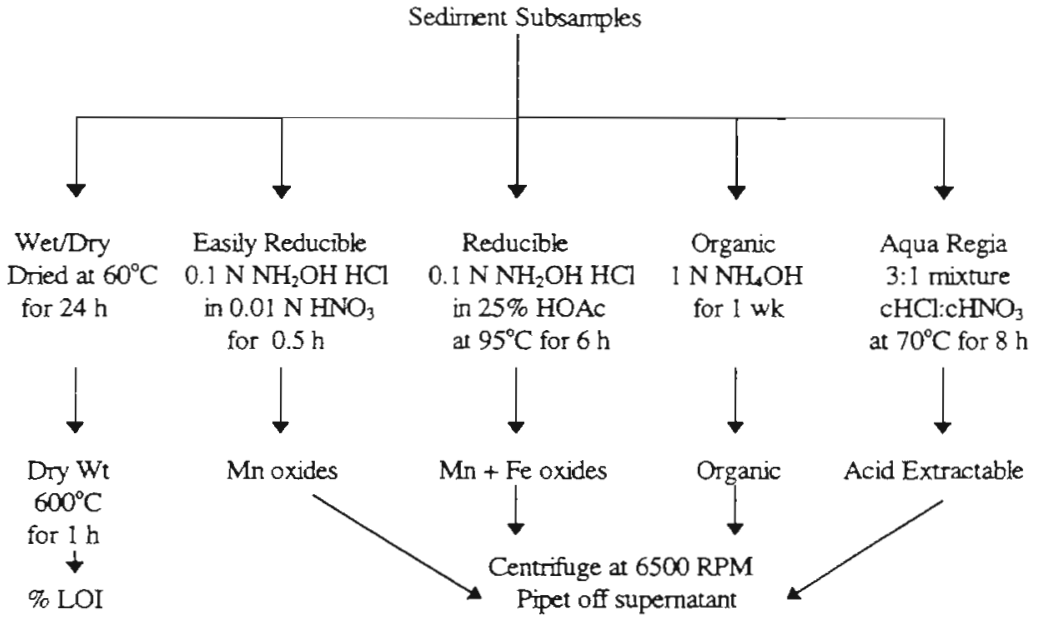

Fig. 2. Simultaneous extraction scheme used to characterise sediment geochemistry

Trace metal analysis: Chemical analyses for metals associated with the different sediment components were carried out in collaboration with the Pacific Environmental Science Center, North Vancouver. The analysis for iron, manganese, zinc, copper and nickel was done by Inductively Coupled Plasma-Atomic Emission Spectrophotometry (ICP-AES). Only the easily reducible fraction was analysed without dilution; the other 3 extracts required $1 / 10$ dilutions to reduce matrix interferences. Standards were matrix matched for each extract to account for matrix quenching. Cadmium and lead were analysed by graphite furnace atomic absorption spectrophotometry (GF-AAS) and were diluted as required $(1 / 5,1 / 10)$. Only the aqua regia extract was analysed for mercury using Cold Vapour Atomic Absorption Spectrophotometry (CVAAS) (ASL labs). Quality assurance/quality control (QA/QC) was maintained by the analysis of reference sediment (MESS-2), and reagent blanks, as well as lab replicates. $\mathrm{QA} / \mathrm{QC}$ results for all parameters analysed demonstrated that precision and accuracy met acceptance criteria. Detection limits ( $\mu \mathrm{g} \mathrm{g}^{-1}$ dry weight) of metals in each sediment extract are included in Table 1.

Matrix determinations: In addition to the above trace metal analysis, the geochemical matrix of the sediment as defined by ER Mn (easily reducible $\mathrm{Mn}$ ), RED Fe (reducible $\mathrm{Fe}$ ), and organic matter (\%LOI), and particle size was determined. To standardize concentrations to dry weight, wet/dry weight ratio was determined by drying a $2 \mathrm{~g}$ subsample of sediment at $60^{\circ} \mathrm{C}$ for $24 \mathrm{~h}$. Loss on ignition was peranalysis. formed on the dried sediment samples following calculation of wet/dry weight by ashing the sample for $1 \mathrm{~h}$ at $600^{\circ} \mathrm{C}$. The sample was weighed before and after treatment to obtain the percent organic matter (\%LOI). Iron oxide concentrations (RED Fe) were determined from the concentration of iron in the reducible phase minus the concentration of iron recovered in the easily reducible phase. Manganese oxide concentrations were determined as the concentration of manganese in the easily reducible phase (ER Mn). Sediment organic matter was expressed as \% LOI.

Grain size: Particle size was determined by hydrometer (Methods of Soil Analysis 1965). This method separates the mineral part of the soil into different size fractions (sand at $0.05-2.00 \mathrm{~mm}$, silt at $0.002-0.05 \mathrm{~mm}$ and clay at $<0.002 \mathrm{~mm}$ ). Particle size analysis was undertaken on a composite sample of the 3 sediment samples taken at each site. Readings on the hydrometer were taken at standard intervals of time known to correspond to settling velocities of different size fractions and percentages of sand, silt and clay calculated based on these results.

Tissue chemistry. A comprehensive sample of benthic invertebrates was obtained during July. Benthic samples were taken in triplicate by box core $(20 \times 20 \times$ $10 \mathrm{~cm}$ ) at the same sampling locations where sediments were taken. Benthic samples were bagged and taken back to the lab where they were sieved and sorted. Everything retained by an $800 \mu \mathrm{m}$ mesh was kept and sorted through for Macoma balthica. Sieving was always completed within $48 \mathrm{~h}$ after removal from the sediment and sorting was done in the following 3 d. M. balthica specimens were frozen until further

Table 1. Detection limits ( $D L_{i} \mu g^{-1}$ ) and dilution factors (DF) for metals in each sediment extract. -: no dilution; na: not analysed

\begin{tabular}{|c|c|c|c|c|c|c|c|c|}
\hline \multirow[t]{2}{*}{ Metal } & \multicolumn{2}{|c|}{ Easily reducible } & \multicolumn{2}{|c|}{ Reducible } & \multicolumn{2}{|c|}{ Organic } & \multicolumn{2}{|c|}{ Aqua regia } \\
\hline & DL & DF & DL & DF & DL & DF & DL & $\mathrm{DF}$ \\
\hline $\mathrm{Cd}^{\circ}$ & 0.006 & - & 0.006 & - & 0.006 & - & 0.06 & 5 \\
\hline $\mathrm{Pb}^{\mathrm{G}}$ & 0.06 & - & 0.20 & $2-5$ & 0.06 & 1.1 & 0.6 & 5 \\
\hline $\mathrm{Cu}^{1}$ & 0.1 & - & 1.0 & 10 & 1.0 & 10 & 1.0 & 1.0 \\
\hline $\mathrm{Fe}^{\prime}$ & 0.1 & - & 1.0 & 10 & 1.0 & 10 & 1.0 & 10 \\
\hline $\mathrm{Mn}^{1}$ & 0.02 & - & 0.2 & 10 & 0.2 & 10 & 0.2 & 10 \\
\hline $\mathrm{Ni}^{\mathrm{I}}$ & 0.4 & - & 4.0 & 10 & 4.0 & 10 & 4.0 & 10 \\
\hline $\mathrm{Zn}^{\prime}$ & 0.04 & - & 0.4 & 10 & 0.4 & 10 & 0.4 & 10 \\
\hline $\mathrm{Hg}^{\mathrm{C}}$ & na & na & na & na & na & na & 0.0005 & 3 \\
\hline
\end{tabular}


After removal from the freezer, Macoma balthica were rinsed with $\mathrm{DI} \mathrm{H}_{2} \mathrm{O}$ to remove any adhered sediment. Specimens were then separated into 2 size classes, 2-6 $\mathrm{mm}$ and 6.1-13 $\mathrm{mm}$. Clams were dissected and the shell was separated from the body. Tissues were dried to a constant weight for $24 \mathrm{~h}$ at $50^{\circ} \mathrm{C}$ (as indicated by no further change in dry weight past the $24 \mathrm{~h}$ drying period). For the $2-6 \mathrm{~mm}$ size class, concentrations of trace metals in the shell and tissue fell below detection. Therefore, only results for the 6.1-13 mm size class are presented. Dried tissue and shell samples were weighed directly into test tubes used for the digestion procedure. Samples were cold digested with $1.0 \mathrm{ml} \mathrm{HNO}_{3}$ for $3 \mathrm{~h}$ and then heated in a digestor at $110^{\circ} \mathrm{C}$ for 4 to $6 \mathrm{~h}$. Test tubes were allowed to cool for a minimum of $30 \mathrm{~min}$, at which point samples were transferred back to the digestor where $0.5 \mathrm{ml}$ of $30 \%$ $\mathrm{H}_{2} \mathrm{O}_{2}$ was added and heated again for $1 \mathrm{~h}$. This last step was repeated once again to ensure the complete breakdown of all lipids. During the entire digestion process, test tubes were capped with watch-glass covers to reduce contamination and loss of volatile elements. After cooling, samples were made up to a volume of $10.0 \mathrm{ml}$ and stored at $4^{\circ} \mathrm{C}$ until analysis. To account for metals associated with sediment in the gut of $M$. balthica, sediment remaining in test tubes after digestion was weighed and back calculated to determine the concentration of associated metal. In all cases, concentrations were negligible relative to tissue concentrations. Biota samples were analysed for cadmium, copper, nickel, lead and zinc by Inductively Coupled Plasma Mass Spectrophotometry (ICP-MS) and mercury was analysed by CV-AAS. Detection limits, in $\mu \mathrm{g} \mathrm{g}^{-1}$, for metals in biota were: $0.01,0.2,0.2,0.1$ and 0.2 for $\mathrm{Cd}, \mathrm{Cu}, \mathrm{Ni}, \mathrm{Pb}$ and $\mathrm{Zn}$ for ICP-MS and 0.004 for $\mathrm{Hg}$ for CV-AAS.

In some cases the amount of sample exceeded the dry weight recommended for the above digestion process. In this case, samples were digested using a CEM MDS-2000 microwave as follows: an initial cold digestion phase where $6.0 \mathrm{ml} \mathrm{HNO}_{3}, 1.0 \mathrm{ml} \mathrm{HCl}$ and $1.0 \mathrm{ml}$ $\mathrm{H}_{2} \mathrm{O}_{2}$ was added to the samples and left overnight. The following day, samples were microwaved for $30 \mathrm{~min}$, cooled and then made up to $30 \mathrm{ml}$ with Nanopure ${ }^{\circledR}$ water Samples were analysed for cadmium, copper, nickel, lead and zinc by ICP-AES. To ensure QA/QC, biota reference material (1566a and TORT-1) and method blanks were analysed throughout the procedure. Results for all parameters met acceptance criteria for precision and accuracy (within $5 \%$ of certified values).

Statistical analyses. Statistical analyses were carried out using SAS v.6.11. For all analyses, concentrations were $\log _{10}$ transformed and percentages were arcsin transformed prior to inclusion into statistical models
(SAS 1988). Due to the unbalanced nature of the sampling design, a 3-way GLM (General Linear Model) was used to determine if there were differences in the sediment geochemical matrix and the concentration and partitioning of metals in the different fractions between months, among sites and locations and the interaction between month and location. Tukey's multiple comparison test was used to determine the significance of any differences among the 3 sites. An $\mathrm{R}^{2}$ MAX procedure was used to determine the relationship between sediment geochemistry and metal levels in the tissue and shells of Macoma balthica. For this procedure, metal levels in $M$. balthica were used as the dependent variable and sediment matrix components and the corresponding metal concentrations in each of the fractions was applied to identify which components of the sediment geochemistry correlated with $M$. balthica metal concentrations. The $\mathrm{R}^{2} \mathrm{MAX}$ procedure finds the best 1 -variable model, 2 -variable model, and so forth with the largest coefficient of determination $\left(R^{2}\right)$ (SAS 1988).

\section{RESULTS}

\section{Metal concentrations and partitioning}

The geochemical matrix of the intertidal region as defined by ER Mn, RED Fe, and \%LOI is summarized in Figs. $3 \& 4$. Concentrations and percent partitioning of metals cadmium, copper, nickel, lead and zinc were measured in each of the operationally defined sediment fractions; ER Mn, RED Fe, ORG and 'near total' and are summarized in Figs. $5 \& 6$ (metal concentrations) and Figs. $7 \& 8$ (metal partitioning). Concentrations of metals in the ORG phase were below detection at most sampling locations; therefore, only results for metals in the ER, RED and RES phases are discussed. 'Residual' (RES) refers to the fraction of metals that are bound tightly within the lattice framework of the sediment and are considered unavailable for uptake by an organism. Mercury was only measured in the 'near total' phase.

Spatial and temporal variability within the estuary, in regards to the sediment geochemical matrix ( $\mathrm{p}<$ 0.0001 for location, site, month; Figs. 3 \& 4) and the concentration (Tables $2 \& 3$ ) and partitioning (Tables 4 $\& 5$ ) of metals was high. This variability precluded the pooling of any locations; however, the general trends were: (1) higher concentrations of metals at Roberts and Sturgeon Bank than Boundary Bay, except for cadmium for which the reverse was true; (2) concentrations in the RES phase were higher in May than in July, while metals in the RED phase were higher in July than May; and (3) for most metals the percent parti- 
Easily Reducible Manganese ( $\mu \mathrm{g} / \mathrm{g})$
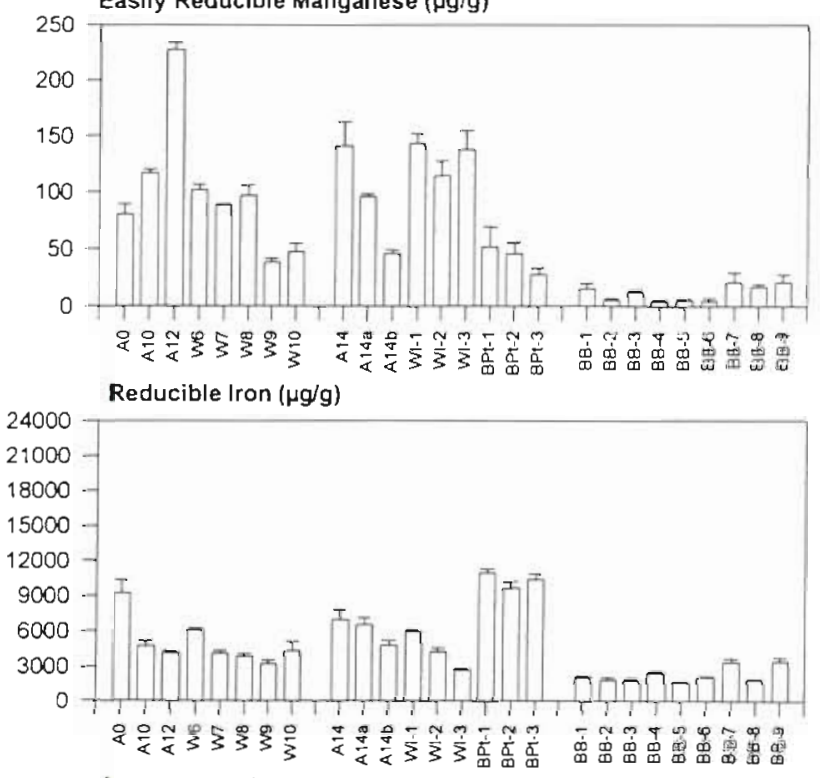

Loss on Ignition (\%)

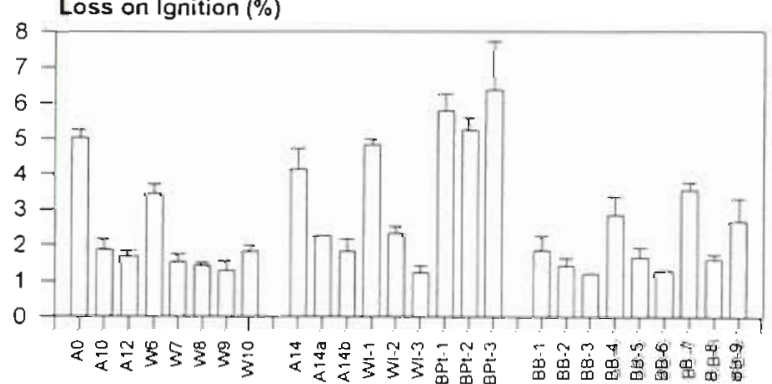

Fig. 3. Concentrations of matrix features in surficial sediment from the intertidal region, May 1995. Values are means of 3 measures $\pm 1 \mathrm{SD}$

tioned in the labile fraction (ER + RED) was greater than $50 \%$ (Table 6 ).

Mercury analysis was only done on the aqua regia extracts from the July sampling period by CV-AAS. Mercury concentrations were significantly different among sites and locations with Roberts Bank having the highest concentrations of mercury and Boundary Bay the lowest $(p<0.05)$. The maximum concentration of mercury was $0.215 \pm 0.019 \mu \mathrm{g} \mathrm{g}^{-1}$ and was measured at location A0 on Sturgeon Bank which is closest to the Iona Island STP. Mercury concentrations were correlated with \% LOI (organic content) in the sediment ( $\mathrm{r}=$ $0.63 ; n=26$ ) (Fig. 9); this correlation was highly significant $(\mathrm{r}=0.91 ; \mathrm{p}<0.0001, \mathrm{n}=25)$ when location $\mathrm{A} .0$ was excluded from the correlation.

\section{Grain size effects}

Mathematical normalization to eliminate the effect of grain size was attempted by multiplying the bulk chemical concentration by a normalization factor obtained from the following formula: $100 / \%$ fine fraction), where the fine fraction is defined as grain size of less than $0.05 \mathrm{~mm}$. Table 7 illustrates the unrealistic concentration values mathematical normalization can produce when the fine fraction of the sediment represents less than $60 \%$ of the sediment as was found in the current study. Horowitz \& Elrick (1988) suggest that grain size normalization should only take place when the fine fraction of the sediment represents at least 50 to $60 \%$ of the sample. Therefore, grain size normalization for bulk trace metal data was not performed

\section{Metals in Macoma balthica}

Relationships between sediment geochemistry and metal levels in bivalves were determined using an $\mathrm{R}^{2}$ MAX procedure with bivalve metal concentrations as the dependent variable and the following as indepen-
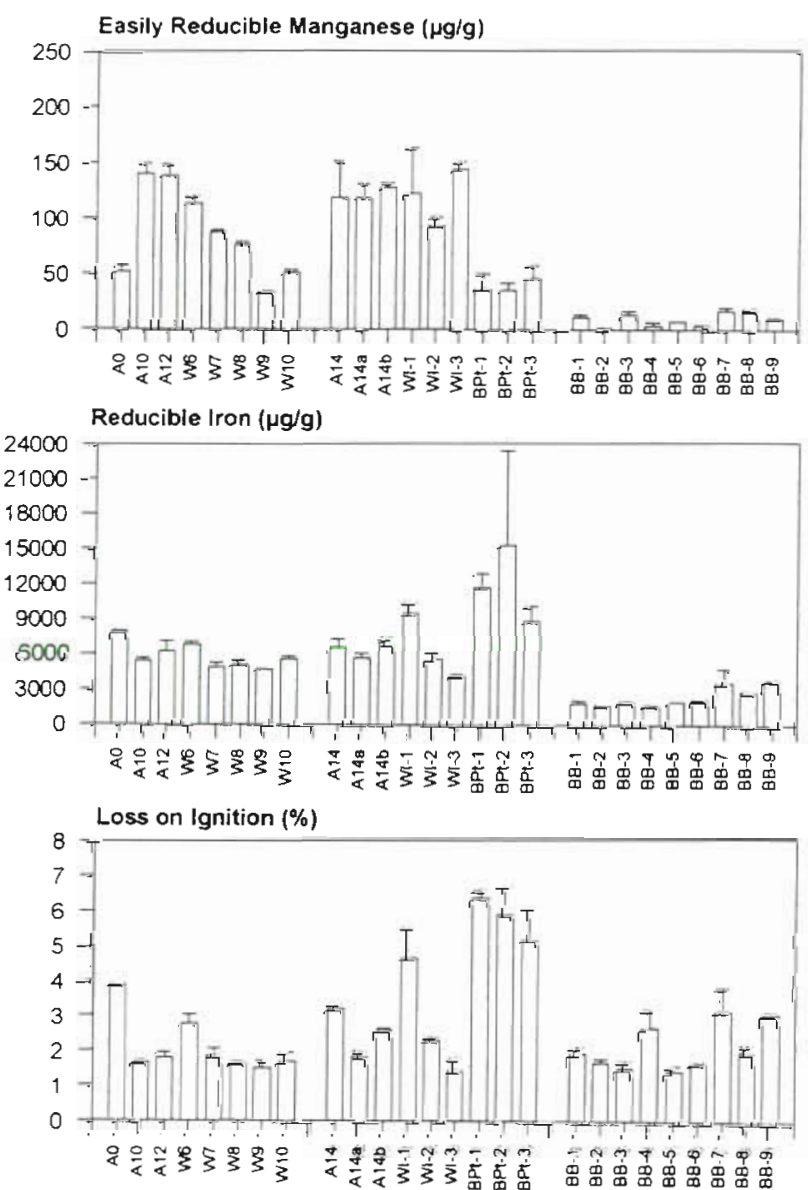

Fig. 4. Concentrations of matrix teatures in surficial sediment from the intertidal region, July 1995. Values are means of 3 measures $\pm 1 \mathrm{SD}$ 
a) $Z n(\mu g / g)$

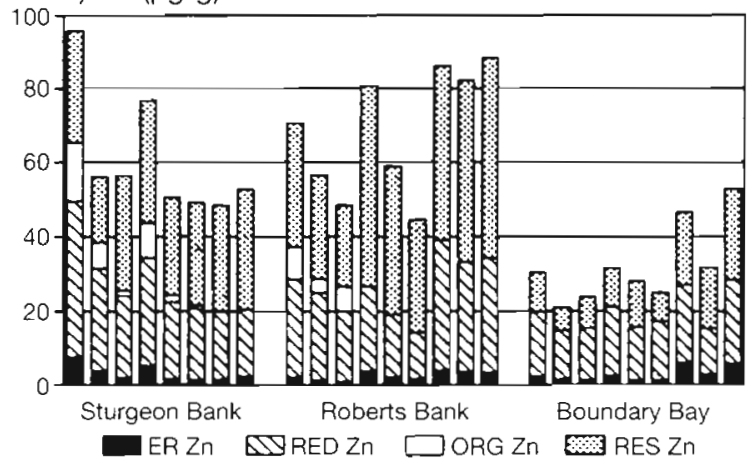

c) $\mathrm{Ni}(\mu \mathrm{g} / \mathrm{g})$

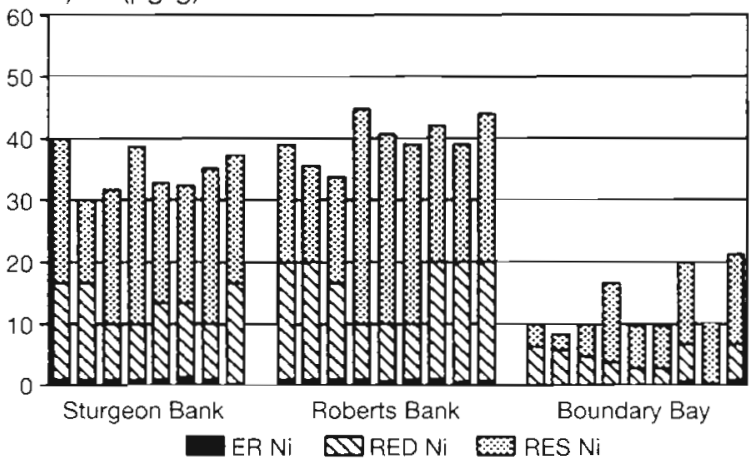

e) $\mathrm{Pb}(\mu \mathrm{g} / \mathrm{g})$

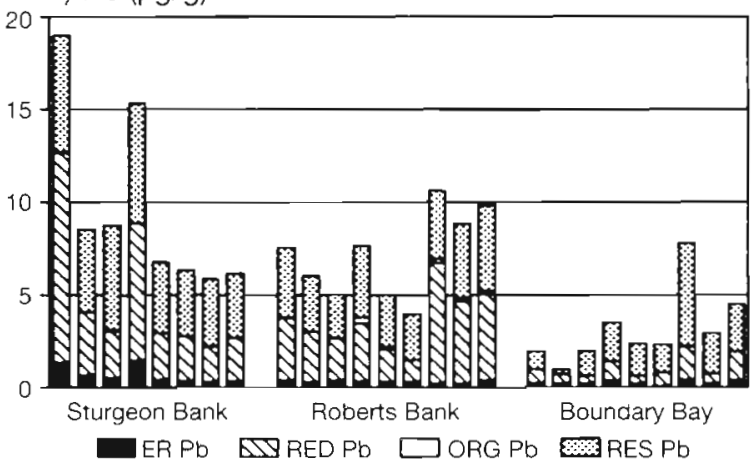

dent variables: ER Mn, RED Fe, \%LOI, ER M, RED M, ORG $M$ and Total $M$ (where $M=$ metal). The $R^{2} M A X$ procedure was used to evaluate the significance of the contribution of each of the variables to the prediction b) $\mathrm{Cu}(\mu \mathrm{g} / \mathrm{g})$

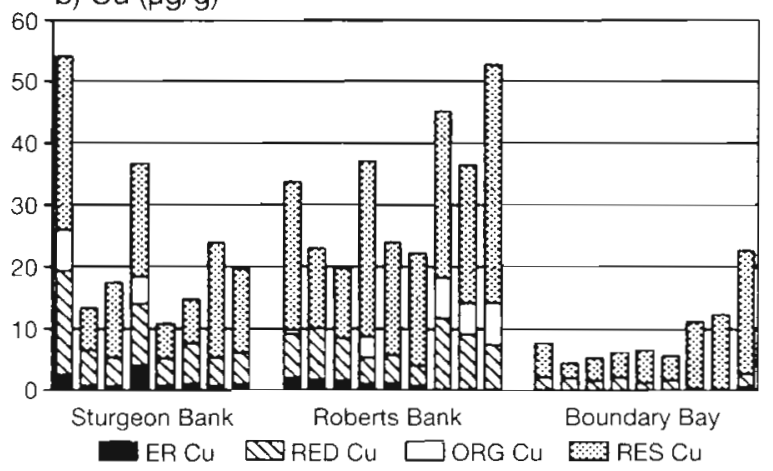

d) $\mathrm{Cd}(\mu \mathrm{g} / \mathrm{g})$

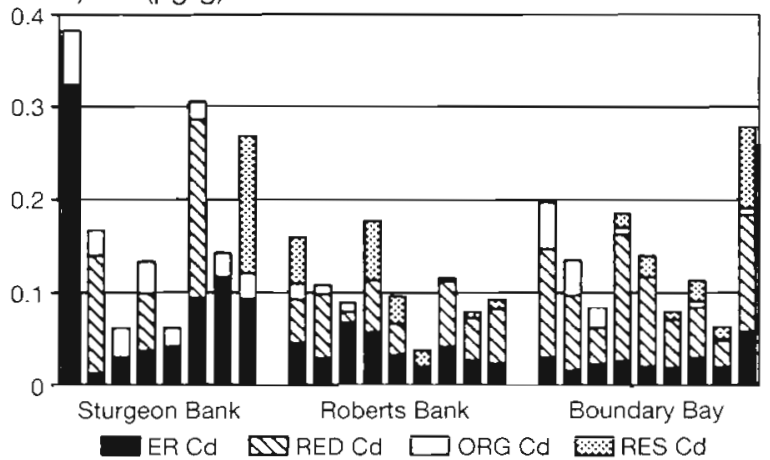

Fig. 5. Concentrations of metals in the different sediment fractions, May 1995. Each location is a mean of 3 samples. Each location within each site (Sturgeon Bank, Roberts Bank and Boundary Bay) corresponds to that noted on Figs. 3 \& 4 . For clarity, SDs have not been presented but, in general, coefficients of variation for each metal in the different sediment fractions were within 5 to $10 \%$

of trace metals in the bivalve. The procedure was performed individually on metals in both the tissue and shell, except for cadmium, where all values were below detection in the shell. Average concentration, range

Table 2. Three-way General Linear Model (GLM) on metal concentrations in the different sediment fractions (ER: easily

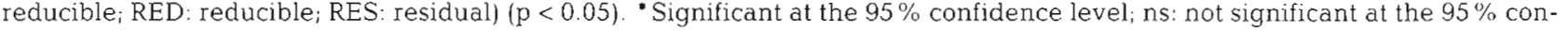
fidence level; $-:$ no comparison possible

\begin{tabular}{|c|c|c|c|c|c|c|c|c|c|c|c|c|c|c|c|}
\hline & \multicolumn{3}{|c|}{ Copper } & \multicolumn{2}{|c|}{ Cadmium } & \multicolumn{3}{|c|}{ Nickel } & \multicolumn{3}{|c|}{ Lead } & \multicolumn{3}{|c|}{$\operatorname{Zinc}$} & \multirow{2}{*}{$\begin{array}{c}\text { Mercury } \\
\text { Total }\end{array}$} \\
\hline & ER & RED & RES & ER & RED & ER & RED & RES & $E R$ & RED & RES & ER & RED & RES & \\
\hline Site & $\cdot$ & $*$ & * & ns & - & $*$ & * & * & * & - & * & ns & - & * & * \\
\hline Location (Site) & $*$ & ns & $\cdot$ & ns & - & ns & ns & * & * & - & * & * & ns & ns & * \\
\hline Month & ns & * & * & ns & ns & ns & * & $\bullet$ & $*$ & * & $*$ & $\mathrm{~ns}$ & ns & ns & - \\
\hline Month $\times$ Location (Site) & * & • & * & $*$ & - & * & * & ns & * & - & * & * & ns & * & - \\
\hline
\end{tabular}


a) $\mathrm{Zn}(\mu \mathrm{g} / \mathrm{g})$

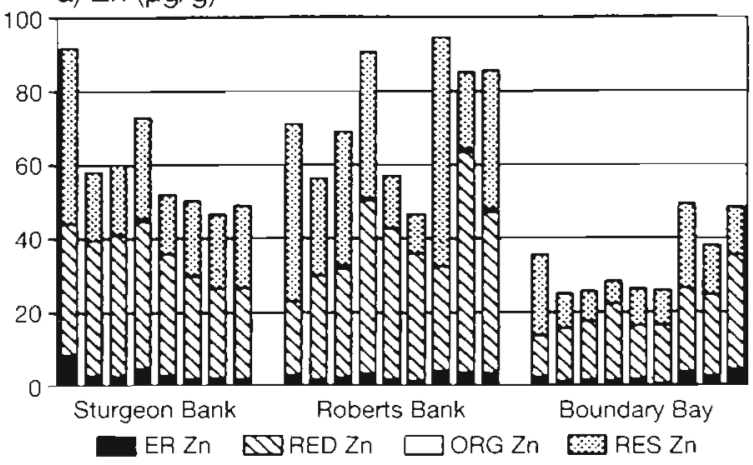

c) $\mathrm{Ni}(\mu \mathrm{g} / \mathrm{g})$

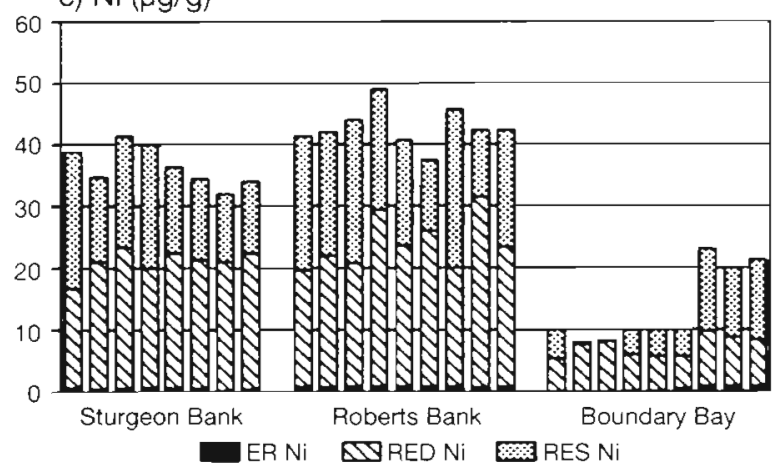

e) $\mathrm{Pb}(\mu \mathrm{g} / \mathrm{g})$

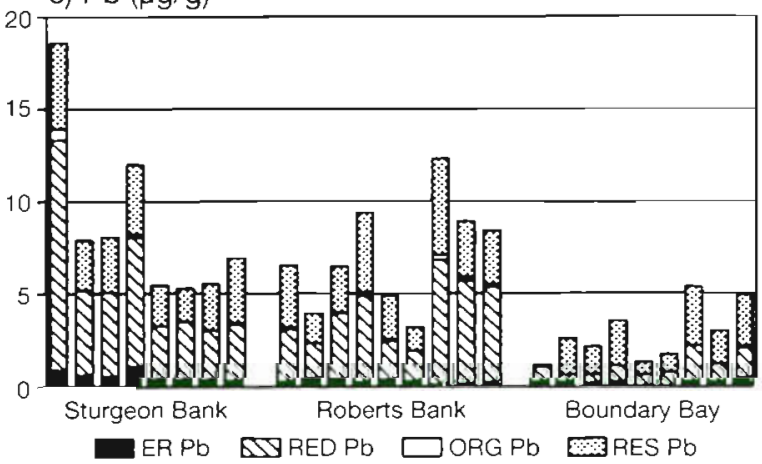

b) $\mathrm{Cu}(\mu \mathrm{g} / \mathrm{g})$

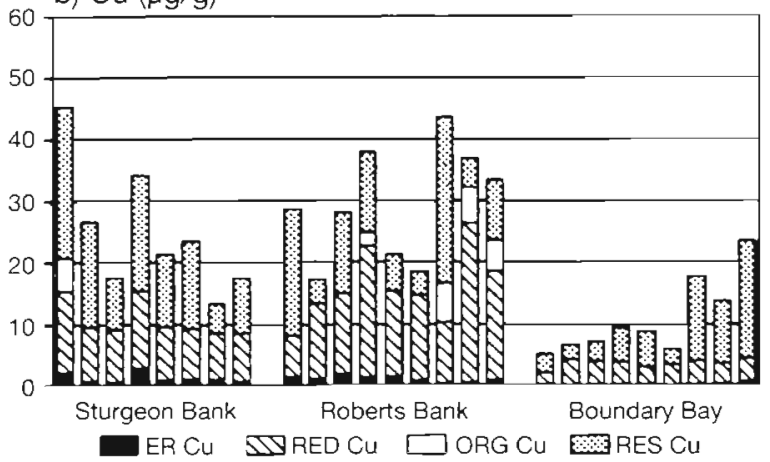

d) $C d(\mu g / g)$
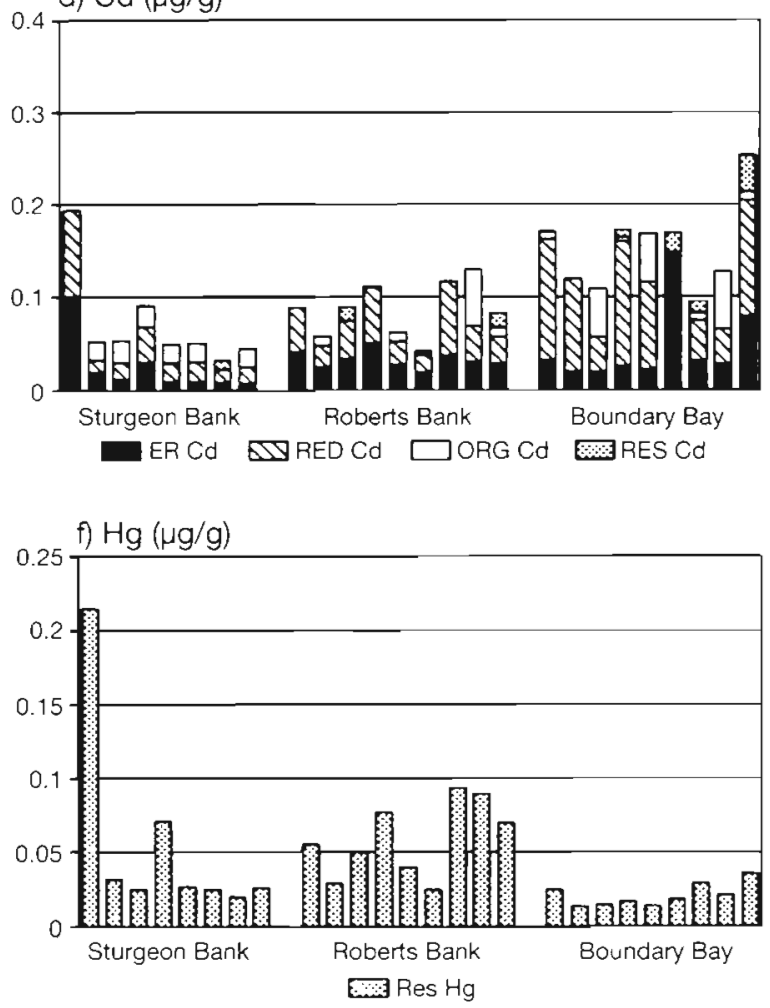

Fig. 6. Concentrations of metals in the different sediment fractions, July 1995. See Fig. 5 for explanations

and coefficient of variation is presented in Table 8 for each metal in the tissue and shell. In all cases, concentrations in the tissue were greater than those in the shell. Table 9 summarizes for each of the metals the independent variables selected, partial regression coefficients and standard error and relevant statistics. All intercorrelated independent variables which were accepted into a model are indicated as such in Table 9.

Cadmium. The $\mathrm{R}^{2} \mathrm{MAX}$ procedure indicated that tissue cadmium concentrations were correlated negatively with RED Fe and positively with ER cadmium (cadmium recovered in the ER fraction). The initial insertion of $\mathrm{RED} F \mathrm{Fe}$ into the analysis produced an $\mathrm{R}^{2}$ value of $0.12(p<0.0145)$ while further addition of $E R$ cadmium improved the $R^{2}$ value to $0.31(p<0.0003)$ Insertion of further independent variables into the $R^{2}$ MAX procedure resulted in only minimal improvement in the $\mathrm{R}^{2}$ value.

Copper. The $\mathrm{R}^{2}$ MAX procedure indicated that copper concentrations in tissues correlated positively with ER and RED copper. The amount of copper recovered in the RED phase (RED copper) accounted for $38 \%$ of the variability in tissue levels $(p<0.0001)$. Further addition of ER copper improved the $\mathrm{R}^{2}$ value to 0.51 $(\mathrm{p}<0.0001)$. Copper concentrations in shells also correlated positively with ER and RED copper, accounting 
a) $\mathrm{Zn}$

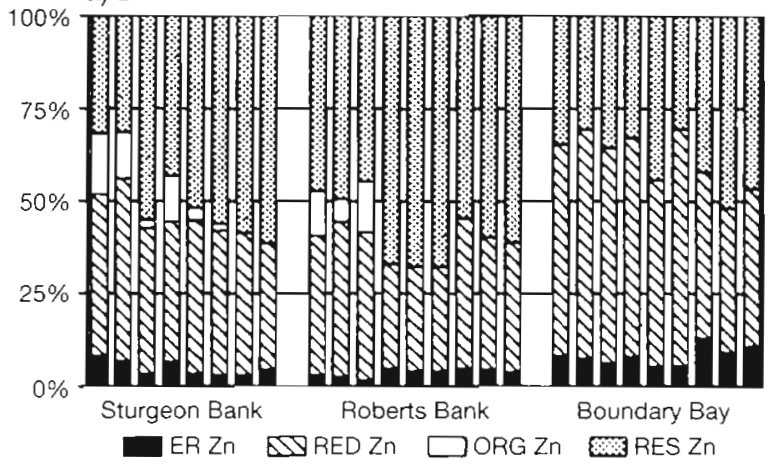

c) $\mathrm{Ni}$

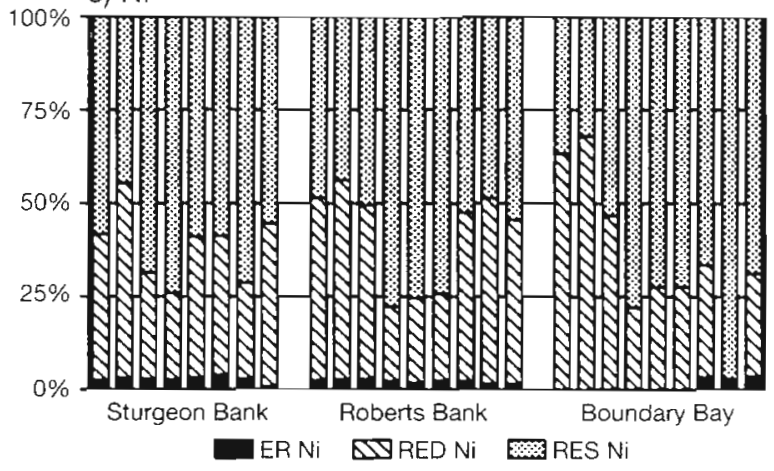

e) $\mathrm{Pb}$

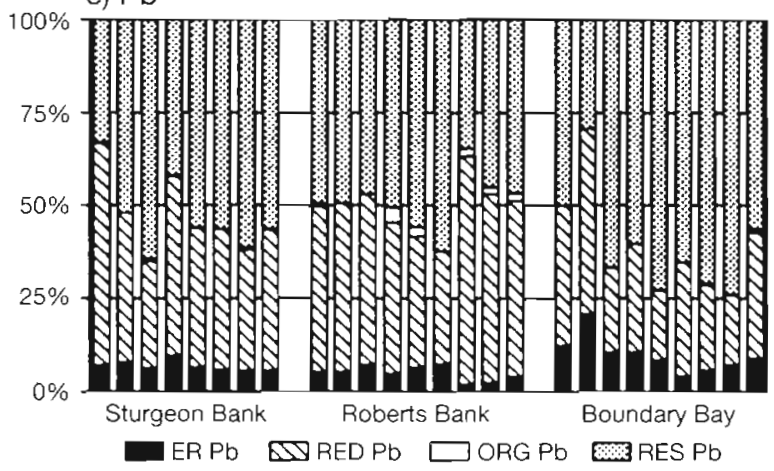

for $43 \%$ of the variability in shell concentrations. The initial insertion of RED copper into the analysis produced an $R^{2}$ value of 0.33 ( $p<0.0001$ ), while further addition of ER copper improved the $\mathrm{R}^{2}$ value to 0.43 ( $p<0.0001)$. Addition of remaining independent variables improved the $\mathrm{R}^{2}$ value by $2 \%$ only. ER copper and RED copper were intercorrelated, $r=0.43, p<$ 0.0018 .

Nickel. The $\mathrm{R}^{2}$ MAX procedure indicated that there were no significant correlations for nickel in the tissues. However, nickel in the shells correlated positively with \%LOI and negatively with total nickel resulting in an $R^{2}$ MAX of 0.21 ( $p<0.0039$ ). The initial insertion of \% LOI into the $\mathrm{R}^{2} \mathrm{MAX}$ procedure generated an $R^{2}$ value of 0.17 ( $p<0.0032$ ), while further addition of total nickel improved the $\mathrm{R}^{2}$ value to 0.21 b) $\mathrm{Cu}$

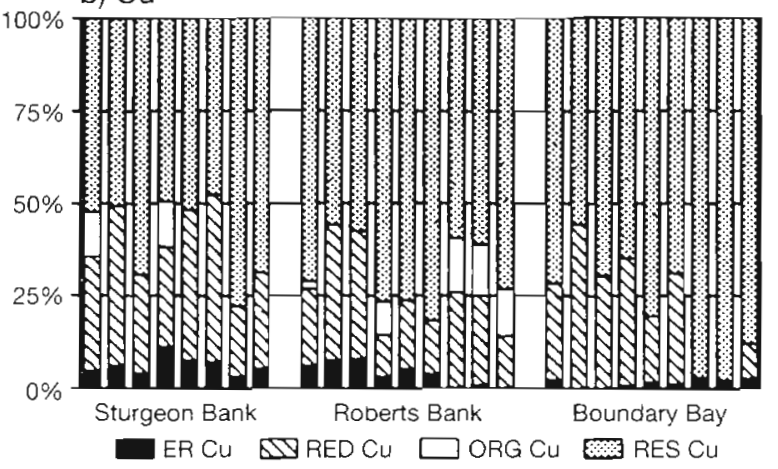

d) $\mathrm{Cd}$

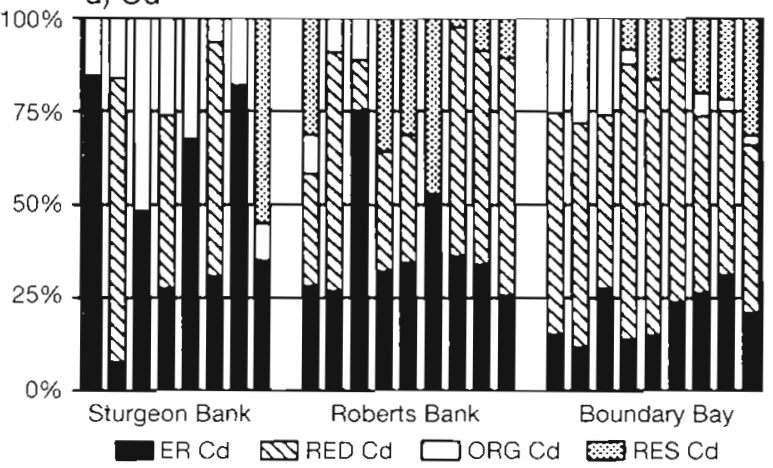

Fig. 7. Partitioning of metals in the different sediment fractions, May 1995. See Fig. 5 for explanations

Table 3. Multiple comparison tests for differences in metal concentrations between months (May and July) and among sites (SB: Sturgeon Bank; RB: Roberts Bank; BB: Boundary Bay) ( $p<0.05$ ). ns: no significant difference. $>$ : significantly greater than based on a $95 \%$ confidence level \% not significantly different from one another based on a $95 \%$ confidence level. -: no comparison possible

\begin{tabular}{|c|c|c|c|}
\hline Metal & Phase & Month & Site \\
\hline Cadmium & $\begin{array}{l}\text { ER } \\
\text { RED }\end{array}$ & $\begin{array}{l}\text { ns } \\
\text { ns }\end{array}$ & $\begin{array}{l}n \bar{s} \\
\mathrm{BB}>\mathrm{RB}>\mathrm{SB}\end{array}$ \\
\hline Copper & $\begin{array}{l}\text { ER } \\
\text { RED } \\
\text { RES }\end{array}$ & $\begin{array}{c}\text { ns } \\
\text { July }>\text { May } \\
\text { May }>\text { July }\end{array}$ & $\begin{array}{l}\mathrm{SB}>\mathrm{RB}>\mathrm{BB} \\
\mathrm{RB}>\mathrm{SB}>\mathrm{BB} \\
\mathrm{RB} / \mathrm{SB}>\mathrm{BB}\end{array}$ \\
\hline Nickel & $\begin{array}{l}\text { ER } \\
\text { RED } \\
\text { RES }\end{array}$ & $\begin{array}{c}\text { ns } \\
\text { July }>\text { May } \\
\text { May }>\text { July }\end{array}$ & $\begin{array}{l}\mathrm{RB}>\mathrm{SB}>\mathrm{BB} \\
\mathrm{RB}>\mathrm{SB}>\mathrm{BB} \\
\mathrm{RB}>\mathrm{SB}>\mathrm{BB}\end{array}$ \\
\hline Lead & $\begin{array}{l}\text { ER } \\
\text { RED } \\
\text { RES }\end{array}$ & $\begin{array}{l}\text { May }>\text { July } \\
\text { July }>\text { May } \\
\text { May }>\text { July }\end{array}$ & $\begin{array}{l}\mathrm{SB}>\mathrm{RB}>\mathrm{BB} \\
\mathrm{SB}>\mathrm{RB}>\mathrm{BB} \\
\mathrm{SB}>\mathrm{RB}>\mathrm{BB}\end{array}$ \\
\hline Zinc & $\begin{array}{l}\text { ER } \\
\text { RED } \\
\text { RES }\end{array}$ & $\begin{array}{l}\text { ns } \\
\text { ns } \\
\text { ns }\end{array}$ & $\begin{array}{c}n s \\
R B / S B>B B \\
R B / S B>B B\end{array}$ \\
\hline Mercury & AR & - & $\mathrm{RB}>\mathrm{SB}>\mathrm{BB}$ \\
\hline
\end{tabular}


a) $\mathrm{Zn}$

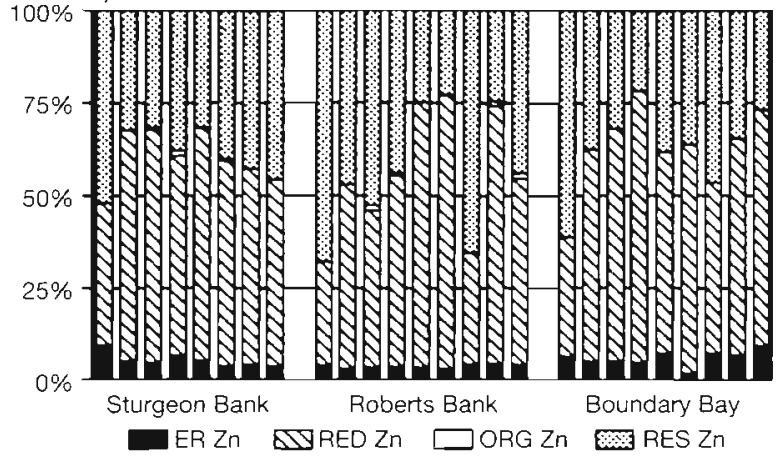

c) $\mathrm{Ni}$

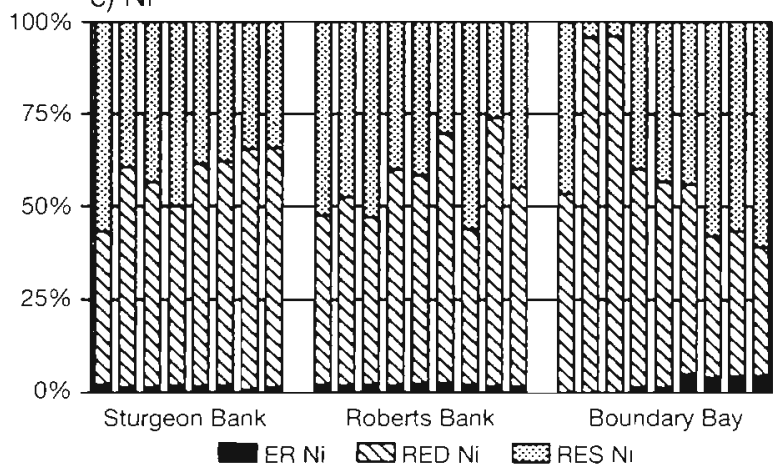

e) $\mathrm{Pb}$

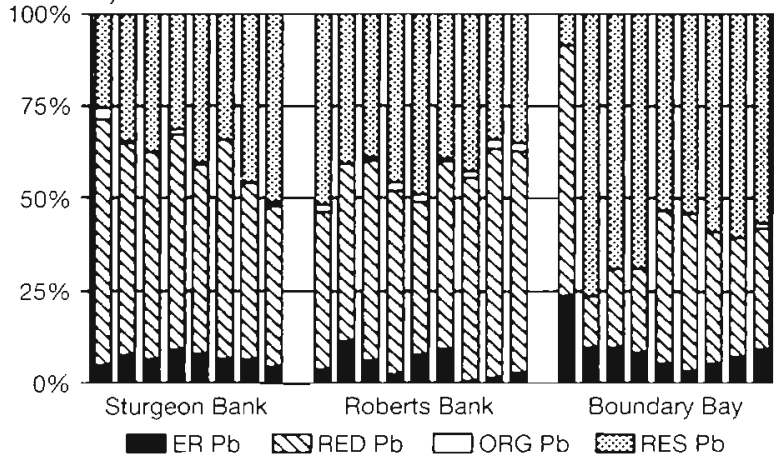

$(p<0.0039)$. Both variables were significantly intercorrelated; \% LOI and ER nickel, $r=0.47, p<0.0006$.

Lead. The $\mathrm{R}^{2} \mathrm{MAX}$ procedure indicated that ER lead correlated strongly with tissue concentrations of lead b) $\mathrm{Cu}$

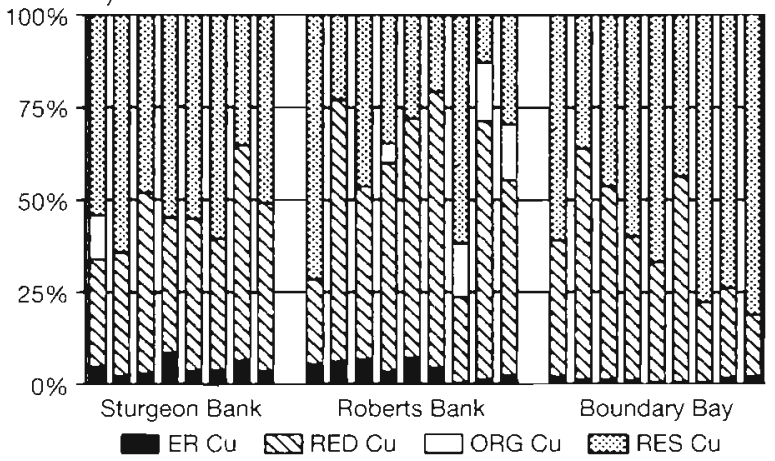

d) $\mathrm{Cd}$

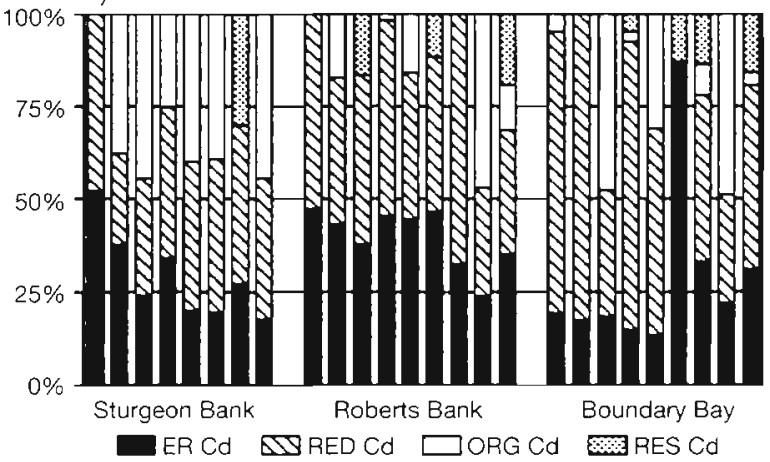

Fig. 8. Partitioning of metals in the different sediment fractions, July 1995. See Fig. 5 for explanations

$\left(\mathrm{R}^{2} \mathrm{MAX}\right.$ of $\left.0.54, \mathrm{p}<0.0001\right)$. Insertion of ER $\mathrm{Mn}$ and then \%LOI into the analysis improved the $\mathrm{R}^{2} \mathrm{MAX}$ from $0.57(p<0.0001)$ to $0.61(p<0.0001)$, respectively. Intercorrelations were observed for $\mathrm{ER} \mathrm{Mn}$ and $\mathrm{ER}$

Table 4. Three-way General Linear Model (GLM) on metal partitioning among the different sediment tractions ( $\mathrm{p}<0.05$ ).

- Significant at the $95 \%$ confidence level, ns: not significant at the $95 \%$ confidence level

\begin{tabular}{|c|c|c|c|c|c|c|c|c|c|c|c|c|c|c|}
\hline & \multicolumn{3}{|c|}{ Copper } & \multicolumn{2}{|c|}{ Cadmium } & \multicolumn{3}{|c|}{ Nickel } & \multicolumn{3}{|c|}{ Lead } & \multicolumn{3}{|c|}{ Zinc } \\
\hline & $E R$ & RED & RES & ER & RED & $E R$ & RED & RES & $E R$ & RED & RES & $E R$ & RED & RES \\
\hline Site & $\cdot$ & ns & • & - & * & - & - & ns & - & - & - & - & " & - \\
\hline Location (Site) & ns & ns & ns & ns & ns & $\mathrm{ns}$ & ns & ns & - & ns & ns & • & ns & ns \\
\hline Month & ns & - & - & ns & ns & - & - & * & $\mathrm{ns}$ & - & - & ns & - & ns \\
\hline Month $\times$ Location (Site) & ns & • & - & • & • & • & - & * & $\cdot$ & - & $*$ & ns & • & * \\
\hline
\end{tabular}


Table 5. Multiple comparison tests for differences in metal partitioning between months (May and July) and among sites (SB: Sturgeon Bank; RB: Roberts Bank; BB: Boundary Bay $(p<$ $0.05)$. ns: no significant difference. $>$ : significantly greater than based on a $95 \%$ confidence level. /: not significantly different from one another based on a $95 \%$ confidence level

\begin{tabular}{|c|c|c|c|}
\hline Metal & Phase & Month & Site \\
\hline Cadmium & $\begin{array}{l}\text { ER } \\
\text { RED }\end{array}$ & $\begin{array}{l}\text { ns } \\
\text { ns }\end{array}$ & $\begin{array}{l}R B / S B>B B \\
B B>R B>S B\end{array}$ \\
\hline Copper & $\begin{array}{l}\text { ER } \\
\text { RED } \\
\text { RES }\end{array}$ & $\begin{array}{c}\text { ns } \\
\text { July }>\text { May } \\
\text { May }>\text { July }\end{array}$ & $\begin{array}{c}\mathrm{SB}>\mathrm{RB}>\mathrm{BB} \\
n S \\
\mathrm{RB} / \mathrm{SB}>\mathrm{BB}\end{array}$ \\
\hline Nickel & $\begin{array}{l}\text { ER } \\
\text { RED } \\
\text { RES }\end{array}$ & $\begin{array}{l}\text { May > July } \\
\text { July > May } \\
\text { May > July }\end{array}$ & $\begin{array}{c}\mathrm{RB} / \mathrm{SB}>\mathrm{BB} \\
\mathrm{ns} \\
\mathrm{ns}\end{array}$ \\
\hline Lead & $\begin{array}{l}\text { ER } \\
\text { RED } \\
\text { RES }\end{array}$ & $\begin{array}{l}\text { May }>\text { July } \\
\text { July }>\text { May } \\
\text { May }>\text { July }\end{array}$ & $\begin{array}{l}\mathrm{BB}>\mathrm{SB}>\mathrm{RB} \\
\mathrm{RB} / \mathrm{SB}>\mathrm{BB} \\
\mathrm{BB}>\mathrm{RB} / \mathrm{BB}\end{array}$ \\
\hline Zinc & $\begin{array}{l}\text { ER } \\
\text { RED } \\
\text { RES }\end{array}$ & $\begin{array}{c}\text { ns } \\
\text { July }>\text { May } \\
\text { ns }\end{array}$ & $\begin{array}{l}\mathrm{BB}>\mathrm{SB}>\mathrm{RB} \\
\mathrm{BB}>\mathrm{RB} / \mathrm{SB} \\
\mathrm{RB}>\mathrm{SB}>\mathrm{BB}\end{array}$ \\
\hline
\end{tabular}

lead, $r=0.65, p<0.0001$ and ER lead and \%LOI, $r=$ $-0.28, p<0.004$. Addition of further variables only improved the $\mathrm{R}^{2}$ value by $2 \%$. In contrast, no significant correlation was found between lead in the shells and the 3 sediment components, as well as the 4 measures of lead recovered from the sediment.

Zinc. The $\mathrm{R}^{2} \mathrm{MAX}$ procedure indicated that there was a strong correlation between tissue concentrations of zinc and concentrations of ER Mr in the sediment $\left(\mathrm{R}^{2}=0.39, \mathrm{p}<0.0001\right)$. Addition of further variables into the $\mathrm{R}^{2} \mathrm{MAX}$ procedure resulted in minor improvement. ER Mn was also intercorrelated with RED Fe, ER zinc, RED zinc and total zinc concentrations. Zinc concentrations in shell samples correlated positively with ER Mn $\left(R^{2}=0.15, p<0.0086\right)$. Easily reducible manganese (ER $\mathrm{Mn}$ ) accounted for the majority of the variation with $15 \%$, while addition of ER zinc, which was intercorrelated with ER Mn ( $r=0.40, p<0.0024)$, improved the $\mathrm{R}^{2}$ but by only $6 \%$.

Mercury. An $\mathrm{R}^{2} \mathrm{MAX}$ procedure of the 3 major sediment components, plus the total concentration of

Table 6. Percent metal partitioned in the easily reducible (ER), reducible (RED), residual (RES) and labile (ER + RED) fractions. Values are averaged from all sampling locations and times

\begin{tabular}{|lrrrr|}
\hline Metal & ER & RED & RES & Labile \\
\hline Cadmium & 32.2 & 47.3 & 20.2 & 79.5 \\
Copper & 4.1 & 37.3 & 58.5 & 41.4 \\
Lead & 7.3 & 42.3 & 50.8 & 49.6 \\
Nickel & 2.6 & 48.6 & 52.8 & 51.2 \\
Zinc & 5.3 & 48.9 & 44.8 & 54.2 \\
\hline
\end{tabular}
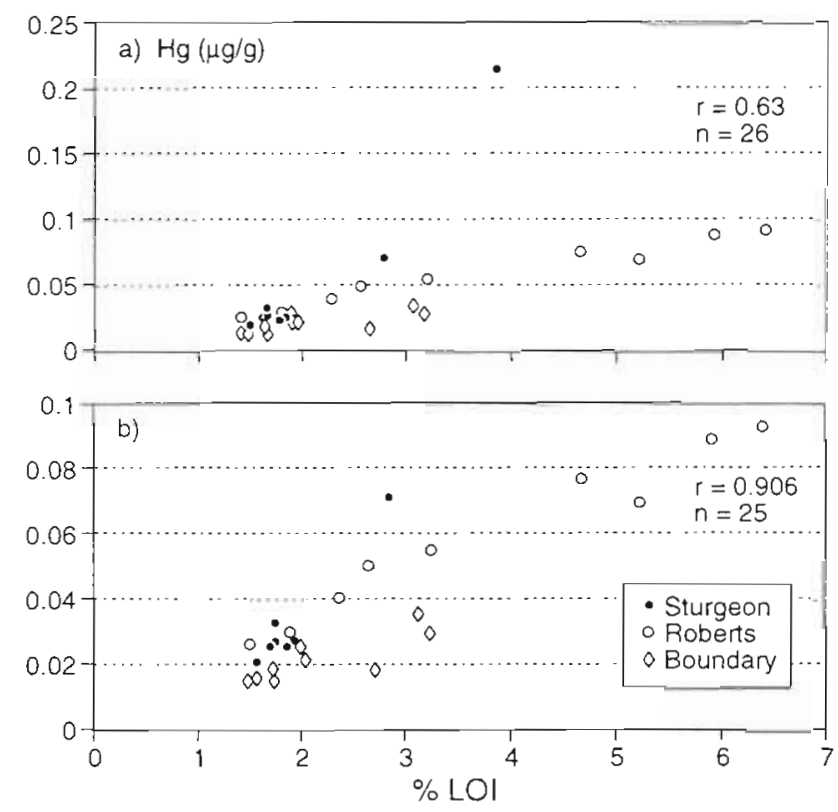

Fig. 9. Correlation between $\mathrm{Hg}$ in the sediment and organic matter; (a) with location AO included within the regression, and (b) with A0 removed from the regression

mercury in the sediment (mercury was only measured in the aqua regia extract), indicated that concentrations of mercury in the shell correlated significantly with ER $\mathrm{Mn}$ in the sediment ( $\mathrm{r}=0.12, \mathrm{p}<0.0436)$. Entrance of further independent variables into the $\mathrm{R}^{2}$ MAX resulted in the deterioration of the $\mathrm{p}$-value. Insufficient data precluded an $\mathrm{R}^{2} \mathrm{MAX}$ on tissue mercury.

\section{DISCUSSION}

Various environmental and biological processes influence the availability of metals to organisms. Determining the geochemical associations of metals provides useful information concerning the origin, absolute levels, mobilization, mode of occurrence and biological availability of a metal. On the other hand, measuring tissue levels in organisms has the advantage of directly measuring the bioavailable fraction. However, only measuring tissue levels does not provide information regarding the processes controlling metal uptake. Combining these 2 techniques allows for a more holistic approach, one that considers the processes influencing bioavailability as well as a direct measure of the bioavailable fraction, with the aim of providing a scientific background for managing ecological systems. For example, if a monitoring program was in place to measure concentrations of metals in Macoma balthica, areas of higher metal bioavailability 
Table 7. Comparison of actual measured concentrations $\left(\mu \mathrm{g} \mathrm{g}^{-1}\right)$ of metals in the RED phase versus those calculated after normalization to the $<0.05 \mathrm{~mm}$ fraction of the sediment in selected samples, determined by multiplying the bulk chemical concentration by a normalization factor obtained from the following formula: $100 /(\%<0.05 \mathrm{~mm})$

\begin{tabular}{|c|c|c|c|c|c|c|c|}
\hline Location & Percent $<0.05 \mathrm{~mm}$ & & $\mathrm{Cu}$ & $\mathrm{Cd}$ & $\mathrm{Ni}$ & $\mathrm{Pb}$ & $\mathrm{Zn}$ \\
\hline WI-3 & 1.2 & $\begin{array}{l}\text { Actual } \\
\text { Calculated }\end{array}$ & $\begin{array}{r}13.9 \\
1154.0\end{array}$ & $\begin{array}{l}0.018 \\
1.53\end{array}$ & $\begin{array}{r}25.0 \\
2083.3\end{array}$ & $\begin{array}{r}1.6 \\
133.6\end{array}$ & $\begin{array}{r}34.5 \\
2877.8\end{array}$ \\
\hline$B B-1$ & 1.0 & $\begin{array}{l}\text { Actual } \\
\text { Calculated }\end{array}$ & $\begin{array}{r}1.9 \\
19.0\end{array}$ & $\begin{array}{l}0.13 \\
1.3\end{array}$ & $\begin{array}{r}5.3 \\
53.3\end{array}$ & $\begin{array}{l}0.8 \\
7.9\end{array}$ & $\begin{array}{r}11.7 \\
113.7\end{array}$ \\
\hline $\mathrm{BB}-7$ & 25.4 & $\begin{array}{l}\text { Actual } \\
\text { Calculated }\end{array}$ & $\begin{array}{r}3.8 \\
15.0\end{array}$ & $\begin{array}{l}0.043 \\
0.171\end{array}$ & $\begin{array}{r}7.3 \\
26.5\end{array}$ & $\begin{array}{l}1.9 \\
7.5\end{array}$ & $\begin{array}{l}22.8 \\
89.8\end{array}$ \\
\hline W6 & 35.7 & $\begin{array}{l}\text { Actual } \\
\text { Calculated }\end{array}$ & $\begin{array}{l}12.5 \\
34.9\end{array}$ & $\begin{array}{l}0.037 \\
0.104\end{array}$ & $\begin{array}{l}19.2 \\
53.8\end{array}$ & $\begin{array}{r}6.9 \\
19.5\end{array}$ & $\begin{array}{r}39.7 \\
111.2\end{array}$ \\
\hline $\mathrm{A} 14 \mathrm{~b}$ & 61.6 & $\begin{array}{l}\text { Actual } \\
\text { Calculated }\end{array}$ & $\begin{array}{l}13.2 \\
21.4\end{array}$ & $\begin{array}{l}0.041 \\
0.067\end{array}$ & $\begin{array}{l}19.7 \\
32.0\end{array}$ & $\begin{array}{l}3.5 \\
5.7\end{array}$ & $\begin{array}{l}29.4 \\
47.7\end{array}$ \\
\hline BPt-3 & 87.2 & $\begin{array}{l}\text { Actual } \\
\text { Calculated }\end{array}$ & $\begin{array}{l}17.8 \\
20.4\end{array}$ & $\begin{array}{l}0.028 \\
0.032\end{array}$ & $\begin{array}{l}22.5 \\
25.9\end{array}$ & $\begin{array}{l}5.1 \\
5.8\end{array}$ & $\begin{array}{l}43.5 \\
49.9\end{array}$ \\
\hline BPt-1 & 96 & $\begin{array}{l}\text { Actual } \\
\text { Calculated }\end{array}$ & $\begin{array}{l}10.1 \\
10.6\end{array}$ & $\begin{array}{l}0.079 \\
0.082\end{array}$ & $\begin{array}{l}19.0 \\
19.8\end{array}$ & $\begin{array}{l}6.8 \\
7.0\end{array}$ & $\begin{array}{l}28.6 \\
29.8\end{array}$ \\
\hline
\end{tabular}

could be identified. However, the processes contributing to these higher tissue concentrations would not be understood.

\section{Metal partitioning}

Partitioning of copper, nickel, lead and zinc in the surficial sediment all followed the same pattern. The RED and RES fractions accounted for the majority of metal sorption with the RES fraction accounting for slightly more in all cases except copper. Previous studies have also found iron oxides (RED phase) to dominate the partitioning of many metals in an estuarine environment (Grieve \& Fletcher 1976, Luoma \& Bryan 1981). However, direct comparison of results with other studies is not always useful considering that different physicochemical factors in different areas will regulate the partitioning of a metal. This was illustrated in the present study, as differences in sediment geochemistry, partitioning and metal concentrations were highly season-and site-specific, precluding pooling of sample locations.

Flow related events may also have influenced the phase distribution of metals. Except for cadmium, RED metals were always higher in July as compared to May, while RES metals were higher in May than July. Geesey et al. (1984) noted that the Fraser River had higher concentrations of reactive metals during periods of decreased flow (July) and higher concentrations of non-reactive metals during periods of high flow (May). They suggest that this is a result of flow characteristics which influenced sediment redox potentials and particle movement. A factor that was not mentioned in the study by Geesey et al. (1984), but can influence the phase distribution of metals, is temperature. As temperature increases, metal partitioning to the particulate phase will increase (Byrne et al. 1988). For example, in July, higher temperatures could have favoured increased partitioning of metals into the RED Fe phase.
Table 8. Macoma balthica. Average concentration, range and coefficient of variation for tissue and shell metal concentrations $\left(\mu \mathrm{g} \mathrm{g}^{-1}\right) . \mathrm{CV}$ coefficient of variation (standard error/average) $\times 100$. bd: concentrations below detection

\begin{tabular}{|lcccccc|}
\hline & Cadmium & Copper & Lead & Nickel & Zinc & Mercury \\
\hline Tissue & $\mathrm{n}=48$ & $\mathrm{n}=45$ & $\mathrm{n}=48$ & $\mathrm{n}=45$ & $\mathrm{n}=49$ & $\mathrm{n}=16$ \\
Average & 0.65 & 84.8 & 2.8 & 12.9 & 287 & 0.214 \\
Range & $0.15-1.5$ & $9.5-308.4$ & $0.5-13.5$ & $4.2-26.9$ & $86-527$ & $0.148-265$ \\
CV & $55.3 \%$ & $85.8 \%$ & $102.9 \%$ & $39.8 \%$ & $49.3 \%$ & $22.4 \%$ \\
Shells & & $\mathrm{n}=42$ & $\mathrm{n}=42$ & $\mathrm{n}=49$ & $\mathrm{n}=45$ & $\mathrm{n}=35$ \\
Average & $\mathrm{bd}$ & 13.1 & 0.68 & 1.7 & 16 & 0.015 \\
Range & - & $2.0-46.9$ & $0.20-1.8$ & $0.11-11.5$ & $0.9-121$ & $0.009-0.036$ \\
CV & - & $61.4 \%$ & $75.4 \%$ & $108.5 \%$ & $138.7 \%$ & $92.6 \%$ \\
\hline
\end{tabular}

\section{Metal concentrations}

Concentrations of copper, nickel, lead and zinc were always lowest at Boundary Bay and highest at Sturgeon or Roberts Bank. However, if locations $A 0$ and W6 (both influenced by the Iona Island STP) are excluded, the highest overall levels of each of the above metals are found at Roberts Bank. Considering that Roberts Bank is estimated to receive $60 \%$ of the municipal and industrial effluent dis- 
Table 9. Macoma balthica. Partial regression coefficients (prc), coefficients of multiple determination $(x)$ and related statistics of prediction of trace metals levels in the tissue and shell of using muliple linear regression $\left(R^{2} M A X\right)$. $X \pm S E$ : estimate of prc and standard error. "Intercorrelated variables in equation

\begin{tabular}{|c|c|c|c|c|c|c|}
\hline Dependent variable & Independent variable & prc & $x$ & $\pm \mathrm{SE}$ & $F$ & $\mathrm{p}$ \\
\hline $\begin{array}{l}\log C d \text { in tissue } \\
N=48\end{array}$ & $\begin{array}{l}\text { Constant } \\
\text { Log RED Fe } \\
\text { Log ER Cd }\end{array}$ & $\begin{array}{l}a_{0} \\
a_{1} \\
a_{2}\end{array}$ & $\begin{array}{r}3.19 \\
-0.74 \\
0.41 \\
\mathrm{R}^{2}=\end{array}$ & $\begin{array}{r} \pm 0.80 \\
\pm 0.18 \\
\pm 0.12 \\
<0.0001\end{array}$ & $\begin{array}{l}16.01 \\
15.92 \\
11.92 \\
5\end{array}$ & $\begin{array}{l}0.0002 \\
0.0002 \\
0.0012\end{array}$ \\
\hline $\begin{array}{l}\text { Log } \mathrm{Cu} \text { in tissue } \\
N=45\end{array}$ & $\begin{array}{l}\text { Constant } \\
\log R_{E D C}{ }^{*} \\
\log E R C u^{*}\end{array}$ & $\begin{array}{l}a_{0} \\
a_{1} \\
a_{2}\end{array}$ & $\begin{array}{c}0.94 \\
0.85 \\
0.47 \\
R^{2}=\end{array}$ & $\begin{array}{l} \pm 0.24 \\
\pm 0.23 \\
\pm 0.14 \\
<0.000\end{array}$ & $\begin{array}{r}14.72 \\
10.89 \\
13.78 \\
1\end{array}$ & $\begin{array}{l}0.0004 \\
0.0020 \\
0.0006\end{array}$ \\
\hline $\begin{array}{l}\log P b \text { in tissue } \\
N=48\end{array}$ & $\begin{array}{l}\text { Constant } \\
\text { Log ER Pb }\end{array}$ & $\begin{array}{l}a_{0} \\
a_{1}\end{array}$ & $\begin{array}{c}0.70 \\
0.83 \\
R^{2}=\end{array}$ & $\begin{array}{l} \pm 0.07 \\
\pm 0.11 \\
<0.000\end{array}$ & $\begin{array}{r}102.83 \\
53.30 \\
3\end{array}$ & $\begin{array}{l}0.0001 \\
0.0001\end{array}$ \\
\hline $\begin{array}{l}\text { Log } \mathrm{Zn} \text { in tissue } \\
\mathrm{N}=49\end{array}$ & $\begin{array}{l}\text { Constant } \\
\text { Log ER Mn }\end{array}$ & $\begin{array}{l}a_{0} \\
a_{1}\end{array}$ & $\begin{array}{c}1.79 \\
0.34 \\
\mathrm{R}^{2}=\end{array}$ & $\begin{array}{l} \pm 0.12 \\
\pm 0.06 \\
<0.000\end{array}$ & $\begin{array}{r}239.35 \\
29.82 \\
62\end{array}$ & $\begin{array}{l}0.0001 \\
0.0001\end{array}$ \\
\hline $\begin{array}{l}\log \mathrm{Cu} \text { in shell } \\
\mathrm{N}=42\end{array}$ & $\begin{array}{l}\text { Constant } \\
\log R E D C u \\
\log \text { ER Cu}\end{array}$ & $\begin{array}{l}a_{0} \\
a_{1} \\
a_{2}\end{array}$ & $\begin{array}{c}0.52 \\
0.28 \\
0.52 \\
\mathrm{R}^{2}=\end{array}$ & $\begin{array}{l} \pm 0.18 \\
\pm 0.11 \\
\pm 0.17 \\
<0.000\end{array}$ & $\begin{array}{r}8.10 \\
6.69 \\
9.32 \\
65\end{array}$ & $\begin{array}{l}0.0070 \\
0.0136 \\
0.0041\end{array}$ \\
\hline $\begin{array}{l}\log N i \text { in shell } \\
N=49\end{array}$ & $\begin{array}{l}\text { Constant } \\
\text { Arcsine LOI } \\
\text { Log total } \mathrm{Ni} \text {. }\end{array}$ & $\begin{array}{l}a_{0} \\
a_{1} \\
a_{2}\end{array}$ & $\begin{array}{r}0.32 \\
0.07 \\
-0.61 \\
R^{2}=\end{array}$ & $\begin{array}{r} \pm 0.55 \\
\pm 0.02 \\
\pm 0.38 \\
<0.003\end{array}$ & $\begin{array}{r}0.34 \\
12.51 \\
2.58\end{array}$ & $\begin{array}{l}0.5653 \\
0.0009 \\
0.1152\end{array}$ \\
\hline $\begin{array}{l}\log Z \mathrm{Zn} \text { in shell } \\
N=45\end{array}$ & $\begin{array}{l}\text { Constant } \\
\text { Log ER Mn }\end{array}$ & $\begin{array}{l}a_{0} \\
a_{1}\end{array}$ & $\begin{array}{l}0.275 \\
0.38 \\
R^{2}=\end{array}$ & $\begin{array}{r} \pm 0.25 \\
\pm 0.14 \\
<0.008\end{array}$ & $\begin{array}{l}1.15 \\
7.58\end{array}$ & $\begin{array}{l}0.2893 \\
0.0086\end{array}$ \\
\hline $\begin{array}{l}\operatorname{Log~Hg} \text { in shell } \\
\mathrm{N}=35\end{array}$ & $\begin{array}{l}\text { Constant } \\
\text { Log total } \mathrm{Hg}\end{array}$ & $\begin{array}{l}a_{0} \\
a_{1}\end{array}$ & $\begin{array}{c}-2.53 \\
0.32 \\
R^{2}=\end{array}$ & $\begin{array}{r} \pm 0.30 \\
\pm 0.15 \\
<0.043\end{array}$ & $\begin{array}{r}71.62 \\
4.40\end{array}$ & $\begin{array}{l}0.0001 \\
0.0436\end{array}$ \\
\hline
\end{tabular}

charged into the Fraser River (Kennett \& McPhee 1988), this implies that the Fraser River is an important source of trace metals to the estuary.

In contrast to the behaviour of the other metals measured, cadmium partitioning and distribution was atypical. A major finding was that the majority of cadmium was recovered in the ER and RED phase, with little recovered in the RES phase. Previous studies have also found that in an estuarine environment very little cadmium partitions into the RES fraction and that the reducible phase serves as an important reservoir for cadmium (Davies-Colley et al. 1984, Kersten \& Förstner 1987). In comparison with other metals, cadmium is characteristically enriched in the more mobile fraction (ER and RED) and, therefore, may be more of a concern from this respect. Given the biological accessibility of ER and RED metals versus RES metals, the existence of cadmium entirely in the labile fraction of the sediment could represent a risk to any exposed organism.
The highest overall levels of cadmium were observed at Boundary Bay and it was the only metal that had higher concentrations at this site than the other 2 sites. Swain \& Walton (1990) noted higher cadmium concentrations in crabs taken from Boundary Bay than those from Burrard Inlet and suggested that the source of this cadmium was from its use as a fungicide, primarily on golf course greens. Cadmium chloride is the active ingredient in these fungicides. Since there are several golf courses in the vicinity of Boundary Bay, as well as agricultural fields, this may indeed be a source of cadmium to this area.

With respect to mercury, highest overall levels were measured at Roberts Bank when location A0 was excluded. Levels of mercury at Sturgeon Bank have decreased from previous years when levels near the Iona Island STP were up to $0.89 \mathrm{\mu g} \mathrm{g}^{-1}$ in 1.979 (MCGreer 1979) and $0.28 \mu \mathrm{g} \mathrm{g}^{-1}$ in 1992 (Levings \& Bravender 1993). The results for mercury agree with several other studies that have shown a high affinity for 
organic matter in the oxic surficial sediment (Lindberg \& Hariss 1974, Langston 1982).

\section{Linking sediment geochemistry to Macoma balthica}

Previous studies in estuarine environments have demonstrated that metal concentrations in invertebrates can, in part, be explained by a combination of metal concentrations within the sediment (Luoma \& Bryan 1982, Rule \& Alden 1996). As one would expect, correlations with tissue metal concentrations are much better for the more easily extractable metals (ER Mn, RED Fe and ORG) than for tightly bound metals (RES or total).

\section{General trends in bivalve metal concentrations}

For over half of the correlations, metal concentrations in the tissue and the shell of Macoma balthica were significantly correlated with the concentration of metal recovered in the ER phase (i.e. metals associated with manganese oxides) as well as with ER Mn it self (i.e. manganese oxides). As expected, correlations were better for the relatively easily extractable metals than for total trace metal concentrations. The only exception was mercury and nickel, which both showed a weak correlation with total levels in the sediment. The importance of the ER Mn phase and the metals associated with it has been demonstrated. Luoma et al. (1995b) found that the concentration of silver associated with the iron and manganese oxides was a reasonable predictor of silver bioavailability to $M$. balthica in estuarine sediments. Also, Bendell-Young et al. (1994) showed that zinc and copper concentrations in chironomids correlated with zinc and copper concentrations associated with the Mn-oxide portion and were modified by amounts of organic matter.

\section{Specific metals}

Cadmium in bivalve tissues was negatively correlated with RED Fe and positively with ER cadmium, that is, cadmium associated with manganese oxides $(r=0.59)$. Hence, higher tissue concentrations of cadmium in Macoma balthica are predicted to occur at sites where concentrations of RED Fe are low and ER cadmium is high. The negative correlation between cadmium tissue concentrations and RED Fe suggests that this component is modifying what cadmium is available for uptake, possibly through a 'protective' or 'competitive' effect. Possible explanations for this inverse dependence are: (1) RED Fe (presumably as iron oxides) that enters the gut competes with uptake sites on the intestinal tract for solubilized metals; (2) RED Fe becomes solubilized in the gut and as a result the iron itself competes with trace metals for uptake sites; or (3) RED Fe adsorbs dissolved trace metals in the external phase, such as on the gill or mantle tissue (Tessier et al. 1994). Rule \& Alden (1996) found that the largest portion of the variance in tissue concentrations of cadmium in 3 estuarine organisms (grass shrimp, blue mussel and hard clam) was also related to the ER cadmium fraction.

The strongest correlation was found between lead tissue and lead in the ER phase ( $r=0.78$ ). Luoma \& Bryan (1978) found that the biological availability of lead to Scrobicularia plana (a deposit-feeding estuarine bivalve) was controlled mainly by the concentration of lead in the sediment extracted with a weak acid digestion similar to that used for the RED Fe fraction, as modified by the effects of iron. Note, however, that the extraction scheme in the above study did not include an ER phase.

Nickel concentrations in the tissues did not correlate significantly with any of the sediment parameters; however, concentrations in the shell correlated positively with \%LOI and negatively with total nickel concentrations $(r=0.52)$. This suggests that higher concentrations of nickel in the shell are found at locations with higher organic matter and low total concentrations of nickel.

A weak correlation was found between shell mercury concentrations and total mercury in the sediment. $(\mathrm{r}=0.34)$. A regression was not attempted for mercury in the tissues as there were insufficient sample numbers. Few studies have addressed the relationship between mercury in shells and sediment-bound mercury, although previous studies have shown a strong relationship between total mercury in the sediment normalised for organic matter and tissue concentrations for Macoma bâlthica in British estuaries ( $\mathrm{r}=0.80$, $\mathrm{r}=0.74$ ) (Langston 1982, 1985). Organic matter is believed to be the most influential variable on mercury tissue concentrations (Rae \& Aston 1982, Langston 1985). Organic matter acts as a modifier of mercury uptake (not unlike iron); hence, higher tissue concentrations of mercury are found at sites concurrently low in organic matter (Breteler et al. 1981, Langston 1982). Nickel and mercury were the only metals for which a correlation with total metal was found.

Copper concentrations in the tissue and the shell were correlated positively with both RED and ER copper, that is, copper associated with iron and manganese oxides $(r=0.65, r=0.71)$. Hence, high concentrations in the tissue and the shell are more likely to occur at sites high in both RED and ER copper. Other studies have found RED Fe and ER Mn. (Bendell-Young 
et al. 1994) and copper in the organic-sulfide fraction (Rule \& Alden 1996) to account for the majority of the variation in tissue copper concentrations. Tissue and shell zinc concentrations correlated positively with concentrations of ER Mn recovered from the sediment ( $\mathrm{r}=$ $0.62, r=0.39$ ). Therefore, high zinc concentrations in Macoma balthica occurred at locations high in ER Mn.

\section{Tissue versus shell}

Metal ions can become incorporated into the crystalline structure of the shell by replacement of calcium in the carbonate complex or by association with the organic component of the shell. The ionic radii of certain metals, e.g. cadmium and lead, resemble that of calcium and are, therefore, more likely to be taken up into the shell matrix in place of calcium (Sturesson 1978). Incorporation of metals into a bivalve shell can occur via 2 processes: (1) physiological uptake, i.e. during shell deposition from mantle tissue; or (2) passive adsorption onto shell surfaces exposed to seawater. In general, the nature of the absorption processes, the complexing capacity of shell proteins, the ionic radii of the metals, genetic variations of the organisms involved, etc., all govern the uptake of metals into shells. Many studies have looked at metals in the shells of bivalves, but only a few have tried to relate levels to those in the environment. For example, Bryan \& Uysal (1978) found that most of the manganese incorporated into the shell matrix came from that ingested from the sediments, while copper, iron and zinc were probably incorporated directly from the overlying seawater.

In some cases, metals will preferentially accumulate in the shell versus the tissue of bivalves. For example, Babukutty \& Chacko (1992) observed higher lead, manganese and cobalt concentrations in the shells of the estuarine bivalve Villotoria cyprinoides var. cochinensis. However, in the present study, all metals were found at higher concentrations in the tissues than in the shell. Some benefits of using bivalve shells rather than tissues as indicators of metal contamination include less variability (factors contributing to a higher variability in tissue-bound metal concentrations include season, age and size) (Bourgoin 1992), negligible depuration rate (i.e. shells will retain a history of past events) (Babukutty \& Chacko 1992) and ease of handling and storage (Koide et al. 1982). In the present study, variability in shell metal concentrations was high, with coefficients of variation in the same range as tissues. This was probably a result of the relatively low concentrations measured in the shell. Considering that shells had significantly lower concentrations of metals, with high variability, tissue-bound metal concentra- tions are the more useful indicator of metal contamination in the sediment of the Fraser River intertidal region.

\section{Summary and implications}

This study demonstrated the importance of sediment geochemistry as a predictor of trace metals levels in Macoma balthica. Tissue concentrations of cadmium, copper, lead and zinc and shell concentrations of copper, nickel, zinc and mercury were found to relate to sediment geochemistry. The relative contributions of the different matrix components and associated trace metals were highly element specific. Only in 2 cases was total metal in the sediment found to be a good predictor of bivalve metal concentrations (nickel and mercury in the shell). Based on the findings of this study, ER metals (metals associated with the ER phase) and the ER Mn phase itself appear to be the most important factors enhancing the bioaccumulation of metals in $M$. balthica.

The present study also demonstrated that spatial heterogeneity in regard to sediment geochemistry and metal partitioning precluded the overall generalization of metal bioavailability in the intertidal area, i.e. studies concerned with trace metal bioavailability need to consider site-specific sediment geochemistry which in turn leads to site-specific patterns in metal bioavailability to organisms within an intertidal region. In our study, this heterogeneity observed for the Fraser River intertidal region was primarily a result of the proximity of the sampling locations to the mouth of the Fraser River estuary, i.e. the Fraser River was found to be a source of ER metal, as were localized sources of contamination such as concentrations of ER cadmium found at Boundary Bay.

\section{LITERATURE CITED}

Babukutty Y, Chacko J (1992) Trace metals in an estuarine bivalve from the southwest coast of India. Ambio 21: $292-296$

Bendell-Young LI, Dutton M, Pick FR (1992) Contrasting two methods for determining trace metal partitioning in oxidized lake sediments. Biogeochemistry 17:205-219

Bendell-Young LI, Chouinard J, Pick FR (1994) Metal concentrations in chironomids in relation to peatland geochemistry. Arch Environ Contam Toxicol 27:186-194

Bordin G, McCourt J, Rodiriguez A (1992) Trace metals in the marine bivalve Macoma balthica in the Westerschelde Estuary (The Netherlands). Part 1: Analysis of total copper. cadmium, zinc and iron concentrations-locational and seasonal variations. Sci Total Environ 127:255-280

Bourgoin BP (1992) Mytilus edulis shell as a bioindicator of lead pollution: considerations on bioavailability and variability. Mar Ecol Prog Ser 61:253-262

Braune BM (1987) Comparison of total mercury levels in rela- 
tion to diet and molt for nine species of marine birds. Arch Environ Contam Toxicol 16:217-224

Breteler RJ, Valiela I, Teal JM (1981) Bioavailability of mercury in several north-eastern U.S. Spartina ecosystems. Estuar Coast Shelf Sci 12:155-166

Bryan GW, Hummerstone LG (1977) Indicators of heavy metal contamination in the Looe Estuary (Cornwall) with particular regard to silver and lead. J Mar Biol Assoc UK 57: $75-92$

Bryan GW, Lancston WJ, Hummerstone LG (1980) The use of biological indicators of heavy metal contamination in estuaries, with special reference to an assessment of the biological availability of metals in estuarine sediments from South-West Britain. Mar Biol Assoc UK, Occas Publ 1

Bryan GW, Uysal $H$ (1978) Heavy metals in the burrowing bivalve Scrobicularia plana from the Tamar Estuary in relation to environmental levels. J Mar Biol Assoc UK 58: 89-108

Byrne RH, Kump LR, Cantrell KJ (1988) The influence of temperature and $\mathrm{pH}$ on trace metal speciation. Mar Chem $25: 163-181$

Cain DJ, Luoma SN (1986) Effect of seasonally changing tissue weight on trace metal concentrations in the bivalve Macoma balthica in San Francisco Bay. Mar Ecol Prog Ser 28:209-217

Davies-Colley RJ, Nelson PO, Williamson KH (1984) Copper and cadmium uptake by estuarine sedimentary phases. Environ Sci Technol 18:491-499

Engel DW, Fowler BA (1979) Factors influencing cadmium accumulation and its toxicity to marine organisms. Environ Health Perspec 28:81-88

Environment Canada (1992) A state of the environment synopsis: the Lower Fraser River Basin. Environment Canada, Vancouver, BC

Feeney T (1995) Physical controls on the distribution of contaminants on Sturgeon Bank, Fraser River Delta, British Columbia. MSc thesis, Dept of. Oceanography, University of British Columbia, Vancouver

Ferns PN, Anderson JI (1994) Cadmium in the diet and body tissues of dualins Calidris alpina, from the Bristol Channel, UK. Environ Pollut 86:225-231

Fraser River Action Plan (1995) Measuring the health of the river. Environmental Quality Program, 1995 Status Report. Environment Canada, Vancouver, BC

Fraser River Estuary Study, Water Quality Work Group (1979) Water quality: summary report. Environment Canada, Victoria, BC

Geesey GG, Borstad L, Chapman FE (1984) Influence of flowrelated events on concentrations and phase distribution of metals in the lower Fraser River and a small tributary stream in British Columbia, Canada. Wat Res 18:233-238

Grieve DA, Fletcher WK (1976) Heavy metals in deltaic sediments of the Fraser River, British Columbia. Can J Earth Sci 13:1683-1693

Harvey RW, Luoma SN (1985) Effect of adherent bacteria and bacterial extracellular polymers upon assimilation by Macoma balthica of sediment-bound $\mathrm{Cd}, \mathrm{Zn}$ and $\mathrm{Ag}$. Mar Ecol Prog Ser 22:281-289

Horowitz A.J. Elrick KA (1988) Interpretation of bed sedıment trace metal data: methods for dealing with the grain size effect. In: Lichtenberg JJ, Winter JA, Weber CI, Fradkin L (eds) Chemical and biological characterization of sludges, sediments, dredge spoils, and drilling muds. ASTM STP 976. American Society for Testing and Materials, Philadelphia, p 114-128

Jenne EA (1968) Controls on Mn, Fe, Co, Ni, Cu, and $\mathrm{Zn}$ concentrations in soils and water: the significant role of hydrous $\mathrm{Mn}$ and Fe oxides. In: Gould RF (ed) Trace inorganics in water. American Chemical Society, Washington, DC, p $337-387$

Kennett K, McPhee MW (1988) The Fraser River Estuary: an overview of changing conditions. Fraser River Estuary Management Program, Vancouver, BC

Kersten M, Förstner U (1987) Cadmium associations in freshwater and marine sediment. In: Nriagu JO, Sprague JB (eds) Cadmium in the aquatic environment. John Wiley and Sons, Toronto, p 51-89

Koide M, Lee DS, Goldberg ED (1982) Metal and transuranic records in mussel shells, byssal threads and tissues. Estuar Coast Shelf Sci 15:679-695

Langston WJ (1982) The distribution of mercury in British estuarine sediments and its availability to deposit-feeding bivalves. J Mar Biol Assoc UK 62:667-684

Langston WJ (1985) Assessment of the distribution and availability of arsenic and mercury in estuaries. In: Wilson JG, Halcrow $W$ (eds) Estuarine management and quality assessment. Plenum Press, New York, p 131-146

Levings CD, Bravender BA. (1993) Recovery of a mud flat from sewage pollution; preliminary results. Abstract. In: Water Quality Workshop Proceedings 1993. Environment Canada, Vancouver, BC

Lindberg SE, Hariss C (1974) Mercury enrichment in estuarine plant detritus. Mar Pollut Bull 5:93-94

Luoma SN, Bryan GW (1978) Factors controlling the availability of sediment-bound lead to the estuarine bivalve Scrobicularia plana. J Mar Biol Assoc UK 58:793-802

Luoma SN, Bryan GW (1981) A statistical assessment of the form of trace metal partitioning in oxidized estuarine sediments. Mar Chem 12:159-181

Luoma SN, Bryan GW (1982) A statistical study of environmental factors controlling concentrations of heavy metals in the burrowing bivalve Scrobicularia plana and the polychaete Nereis diversicolor. Estuar Coast Shelf Sci 15: $95-108$

Luoma SN, Davis JA (1983) Requirements for modeling trace metal partitioning in oxidized estuarine sediments. Mar Chem 12:159-181

Luoma SN, Cain D, Hornberger M, Brown C. Axtmann E (1995a) Metal bioavailability and organism/population effects. In: Eighth Annual NABS Technical Information Workshop on The Use of Benthic Ecology in Assessing Sediment Contamination. Keystone, Colorado, May 1995, p $32-54$

Luoma SN, Ho YB, Bryan GW (1995b) Fate, bioavailability and toxicity of silver in estuarine environments. Mar Poll Bull 31:44-54

McGreer E (1979) Studies of the bivalve, Macoma balthica (L.) on a Inudflat receiving sewage effluent and on an unpolluted mudflat, Fraser River Estudry, British Columbia. MSc thesis, Dept of Oceanography, University of British Columbia, Vancouver

Methods of Soil Analysis (1965) Part 1-Physical and mineralogical methods, 2nd edn. In: Klute A (ed) American Society of Agronomy. Soil Science Society of America Book Series, No. 5

Rae JE, Aston SR (1982) The role of suspended solids in the estuarine geochemistry of mercury. Wat Res 16:649-654

Rapin F, Tessier A, Campbell PGC, Carignan R (1986) Potential artifacts in the determination of metal partitioning in sediments by a sequential extraction procedure. Environ. Sci Technol 20(8):836-840

Roesijadi G (1992) Metallothioneins in metal regulation and toxicity in aquatic animals. Aquat Toxicol 22:81-114

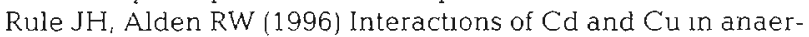


obic estuarine sediments. II Bioavailability, body burdens and respiration effects as related to geochemical partitioning. Environ Toxicol Chem 15:466-471

SAS (1988) SAS/STAT user's guide, Release 6.03 edition. SAS Institute, Cary, NC

Shea D (1988) Developing national sediment quality criteria. Environ Sci Technol 22:1256-1261

Soto M, Kortabitarte M. Marigómez I (1995) Bioavailable heavy metals in estuarine waters as assessed by metal/ shell-weight indices in sentinel mussels Mytilus galloprovincialis. Mar Ecol Prog Ser 125:127-136

Sturesson U (1978) Cadmium enrichment in shells of Mytilus edulis. Ambio 7:122-125

Swain LG, Walton DG (1990) Report on the 1989 Boundary Bay monitoring program. Fraser River Estuary Monitoring. Environment Canada, Victoria, BC

Swain LG, Walton DG (1994) 1993 survey of sediments and tissues from Boundary Bay and Roberts Bank. Fraser River Estuary Monitoring, Environment Canada, Victoria, BC

Editorial responsibility: Otto Kinne (Editor), Oldendorf/Luhe, Germany
Tessier A, Buffle J, Campbell PGC (1994) Uptake of trace metals by aquatic organisms. In: Buffle J, Devitre RR (eds) Chemical and biological regulation of aquatic systems. CRC Press, Boca Raton, FL, p 197-231

Tevendale TJ, Eng P (1984) Rationale for selection of a deep sea outfall to serve the Iona Island Sewage Treatment Plant. In: The workshop on municipal marine discharge. Environmental Protection Service, Pacific Region, Environment Canada, Vancouver, BC

Walsh K, Dunstan RH, Murdoch RN (1995) Differential bioaccumulation of heavy metals and organopollutants in the soft tissue and shell of the marine gastropod, Austrocochled constricta. Arch Environ Contam Toxicol 28:35-39

Young DR, Mearns AJ, Jan TK (1987) The cesium potassium index of food web structure and biomagnification of trace elements in a polluted harbor of southern California. In: Lindberg SE, Hutchinson TC (eds) Heavy metals in the environment. CEP Consultants Ltd, New Orleans, p $74-76$

Submitted: February 5, 1998; Accepted: July 15, 1998 Proofs received from author(s): October 8,1998 